Portland State University

PDXScholar

Dissertations and Theses

Dissertations and Theses

$5-13-1968$

\title{
A Clarification and Evaluation of Black Power
}

Beverly Jo Olson

Portland State University

Follow this and additional works at: https://pdxscholar.library.pdx.edu/open_access_etds

Part of the Social and Behavioral Sciences Commons

Let us know how access to this document benefits you.

Recommended Citation

Olson, Beverly Jo, "A Clarification and Evaluation of Black Power" (1968). Dissertations and Theses. Paper 501.

https://doi.org/10.15760/etd.501

This Thesis is brought to you for free and open access. It has been accepted for inclusion in Dissertations and Theses by an authorized administrator of PDXScholar. Please contact us if we can make this document more accessible: pdxscholar@pdx.edu. 
An abstract of the thesio of

Borrerdy Jo olson for the Master of Bcience in reaching

Date thesis is prosented: Nay $13+1968$

Titile: A Clarification and Evaluation of Elack Fower

Abstract approved:

Norman N. Gteene

Black Americans have entered a new phase in the Civil Rights Hovoment. First they struggled for their legal rights. Then they struggled for equality, whioh meant integration and implementation of their legai rights. Now they struggle for power-m"black power".

"Black power" 1 a motaphow which became part of the Engitish language less than two years ago. Because of its nesness, it has not been clearly defined nor its puxposes clarifled and ovaluated. This paper is A Claxification and Evaluation of Black Dowex.

Black power serves as a rajlying call for unity and self-help among biack poople. But the words are more than slogan. They stand for a mood and a program. The mood is one of worthiness-black is good, black is beautiful--not the inferioxity of past generations. The program, although not well defined or organized, has throe types of goals. They are culturel, economic, and poltitical. The basic cultural goal is untty. The basic economic goal is to raise the black standand of Living. Control or rightelil share of control is the bagic political goai.

The masses of Black Amertca are engaged in this Struggle for 
Power. They have lived through a "xevolution of expectations". Now they want some tanglble results. They want socto-econoric gatns, including botter jobs, housing, and oducation.

They now belleve the best way to achleve these ends is to work togethor as a woup, not separately as individuals. They feel they were oppressed as a group, tho they must leave the oppression as a group. As the group closea ranks, it is accused of racisin and escapism. Actually, the separatisn, which blioks are now advocating, is a realletic solution to a pluralistio soclety.

Violent action and/or the throat of violent action axe vory xoal forees in Amerton today. The Ideology of black power does not call for this Violence, but sowe of the advocates do. They soe violence as a means to an and. It is unfortunate that bleck power has becone so olosely linked with violenee, sinee this tends to mitigate its constructive value.

The idoology and practice of black power needs to be clarifled and evaluated, not by an modomic, but by blaok poople. The time for ambigutty is past. Elack poople need to define their goalo. Then they noed to organige their individual atrengthe into group action. A united flack America, with otrong loadorship and oxtganization, may woll be able to ratso its standard of living and soize 1to wighthil first class eitizenship.

The ldoology and proctice of black powex does ofter* to black

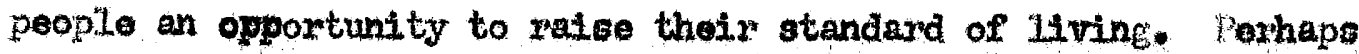


more Important, however, black power allows black people to think woll of themselves, which is, of course, psychologieality healthy. Time may prove me wrong, but this whtex feels history w111 pass a favorable judgment on the struggle for Powerm-Elack Power. 
A CLARTEICATION AND EVALUATION OR BLACK RONER

by

Beverly Jo 01son

A THESIs

SUBMTTTED TO

PORTLALD STATE COLLRGE

IN RARTIAL TULFILLWENT OF

THE REQULRAMENTS FOR THE DEGREE OF

MASTER OF SCIENCE IN TRACHING

June 1968

PORTLAND STATE COLLEGE

LIBRARY 
Approved:
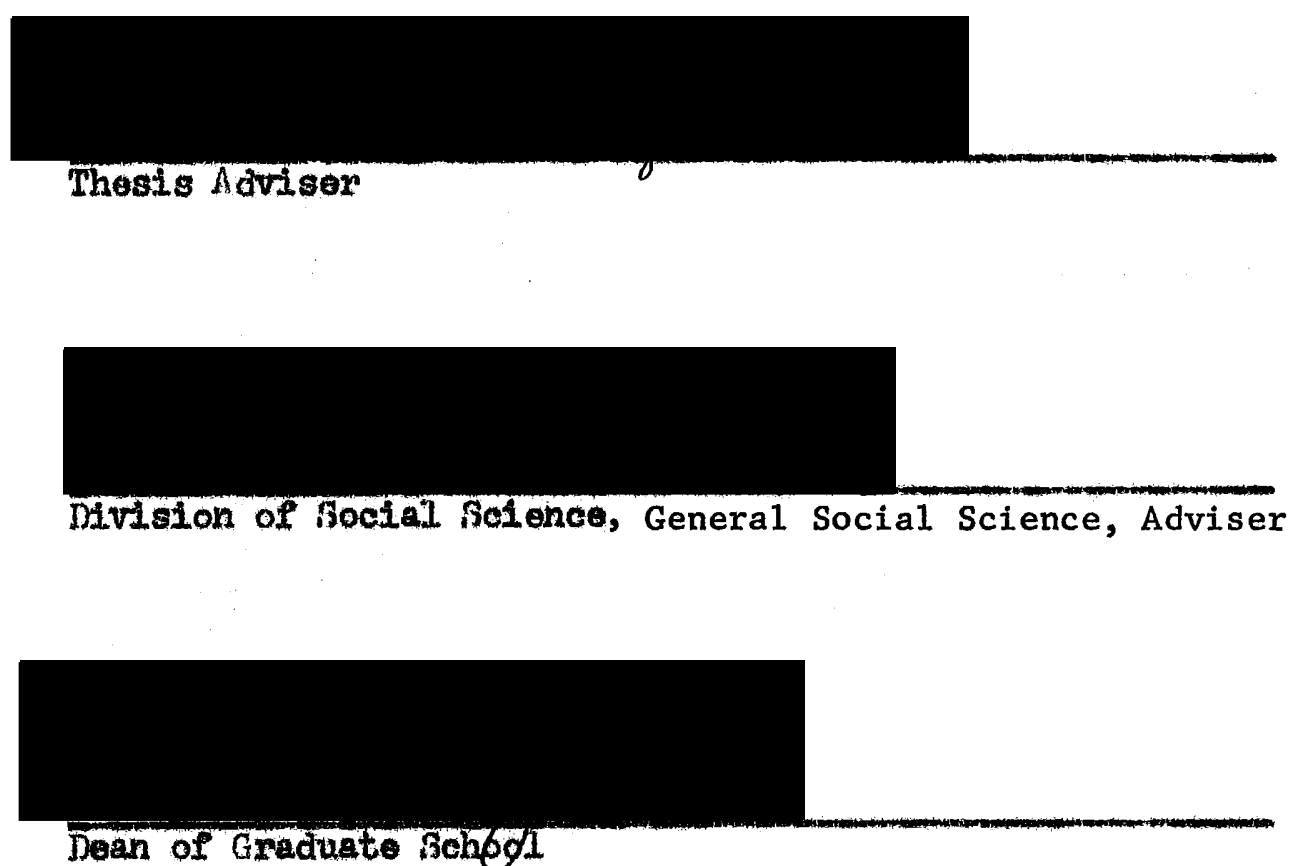

Dean of Graduate Beheoi

Date Thesis Is Fresented: May 13, 1968 
TABLE OF OARTENT

CHAETER

PART I THE CLARTICATION OY BLACK EOWLR. , * . 1

1 Black America Begins to Hopa . . . . . . . . . . . . 2

The struggte for Legal Rights. . . , ..., . . . , 3

The Struggle for Equality. . ............, . . .4

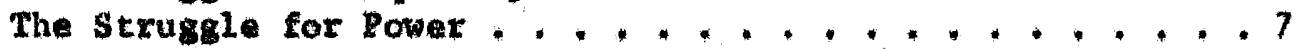

2 The Paychology of Black Amarica. . . . . . . . . . 9

The Role of "Vegro", . . . . . . . . . . . . . 9

The Black Yamliy ....................10

Summary, ...........................13

3 The Ideology and Practice of Black Power , . . . . . . . 14

The Cultural Goals of Black Power, . . . . . . . . . . 17

The Economic Goals of Black Power. . . . . . . . . . . 20

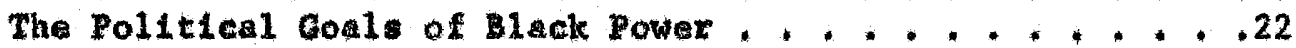

Black Power and Violence.................. . . . . . . .

Surrmary. . . . . . . . . . . . . . . . . . . 29

PART II; THE EVALUATION OF BLACK ROWER, , . . . 31

4 The Evaluation of Black Power. . . . . . . . . . . . . .

Why Black Power and Why Now? , . . . . . . . . . . 34

The Group or Individunlism?................440

Integration or Sepayatsa? ................44

Violence or Kon-violence?. . . . . . . . . . . . .47

Are the Economics and Polltical coals of Black

Power Realistle? . . . . . . . . . . . . . . .52

What Are the Organizational Needs? . . . . . . . . .57

5 Black Powar and the Future..................54

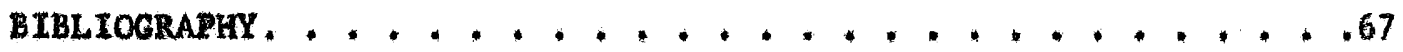


PART I

THE CLARIFICATION OF BLACR POWER 
CHAPTER 1

BLACK AMERICA BEGINS TO HOPE

In the United States today there are approximately twenty million black citfzens, This ten percent of the total population is descended from the Afrlcans who were brought to this country as slaves, These people have endured slavery, the Civil War, the dreams of Raconstruction, the deprivation born of poverty, and second class cltizenship. They were denled their African culture, but not allowed to be fully assimilated into the "American Way of Life." In essence, we White American have ralegated these black people into a colonial situation very similar to that of the African aborigines. The major difference is that in Africa the natives had an ethnte identity, a nationality or tribal awareness, which was separate from the European powers. Black Amertcans have no auch ethnic complenentarity. Britain and France walked away from thelr colonial nations In Africa, but white America cannot walk away from Black America, even though she has attempted to do that very thing.

Before World War II the plight of the Black Amertcan was considered a southern phenomenon, which was to be tolerated or Ignored. The white man had his place, and the black man had his. Both raclal groups knew and generally accepted thelx respective roles. World War II brought with 1t an ldeology of freedom, some integration, the GI B111, and mobility. Individual black men found that they could play other roles besides the inferior one assigned in the south. 
The Struggle for Legal Rights

The years between World War II and 1954 constitute the first phase of the Civil Rights Movement. The only aetive national civil rights group was the National Association for the Advancement of Colored Teople (NAACP) which sponsored a number of Supreme Court declalons. These decisions reafimed for Black Americans most of the rights which the post-Civil War Congress Intended to secure when it proposed the adoption of the Thirceenth, Fourteenth, and Ifteenth Amendments to the Constitution, The NAACP was able to win for the people the right to vote in the crucial primary elections in the south, as well as in general elections, Ordinanceg, passed by southern clties, restricting the aress in which blacks might live were held void. Systematic exclusion of blacks from grand and petit jurles in criminal cases was prohibited. Racial gegregation on interstate busges and rallroads was struck down, White property owners could no longer obtain court enforcement of racially restricted covenants or damages for the breach of same. Lower federal court decistons equaliged the salaries of black teachers. In short, the NAACP spongored long list of court declsions, which brought the black eftizen close to the post-Civil War Congress' goal of equal legal rights.1

This was a legal equality, which brought little action from the white establiahment and 1ittle hope to blacks. Only Individual blacks of the middle class, who had sponsored the changes in response to their

\footnotetext{
1Grant s, Mcclellan, ed., Civil Rights (New York, 1964), p. 54.
} 
own changing economic conditlons, ${ }^{2}$ felt optimistic.

The Struggle for Bquality

It was not until May 17, 1954, however, that the race as a whole began to realize that there was the possibility of asouming other roles than the one designated by the south. On that date the supreme Court of the United State declared the doctrine of "separate but equal" as applied to education unconstitutional and ordered the southern chools integrated.

Black Americans had never regarded the old biracial syotem as right or natural, but unt11 1954 faw saw any possibility that things could change. Then there was a "revolution in expectations."

Thi "revolution in expectations" was sparked and austained for the following reasons:

1. The Supreme Court, the very pinnacle of the white establiahment, had acted in support of, not in opposition to, the black race.

2. The actual struggle to carry out the court dectsion gave them a courage and a w11 they did not know they had.

3. Blacka realized that the north finally grasped the full meaning of raciom by watehing the southern whites.

4. The federal goverment acted,

2Frances Fox Piven and Richard A. Cloward, "What Chance for Black Power?" The New Republic, CLVIII (March 30, 1968), 20.

${ }^{3}$ Bverett car11 Ladd, Jx., Negro Polltcleal Laaderghip in the South (Ithica, N. X, 1966), p. 24. 
5. There was evidence that President Eizenhower was wrong when he said, "I don't belleve you can change the hearts of men with laws or dectgions. "14

The first phase of the Civil Rights Movenent was a struggle for Legal Rights (e.g., the right to vote, freedon of speech, and right to assemble). This phase was for equality..$^{5}$ riret, equality meant the Implementation of the legal decisions of phase one. Secondly, it meant integration as both means and end.

Probably the most important organization during the struggle for Equality was the Southern Chxistian Leadership Conference, under the direction of the charianatic Dr. Martin Luther King, Jr. The late Dr. King led and organiad sit-ins, freedon rides, mass marches and demonatrations, and voter regietration drives, His greatest contribution, however, was the moral edge he gave the movement 1 th his strict adherence to non-violence. He captured the hearts of the working class black people, who became more hopeful more and more public faclitites, ach as lunch counters and busses, wer integrated. His non-violent approach was acceptable to 11beral whites; and they supported him financially and physteally.

The early 1960 ' brought a new group of people and new organizations into the 8 truggle for Equality. The people were college students, whites from the north and blacks frow the south. The organtzations were the Student Non-Violent Coordinating Comattee (SNCC) and the Congress

\section{Mecle11an, PP, 11-14.}

SDaniel Ratrick Moynihan, "Employment, Income, and the Ordeal of The Negro Family," Daedlus, Fal1 1965, pp. 745-746. 
of Raclal Equality (CORE). These young people, skce and CoRe meabers, Integrated themselves physically, intellectually, and emotionally. 6 They worked for equality by practicing the non-violent, direct action approach of the Southern Chriatian headership Conference, sclc. These Integrated young people were quite happy with capitalism, Chriotianity, and the Constitution. 7 The blacks just wanted in and the whites wanted them in. The black college atudent decided to join the struggle for Equality, even though their college officlals, old line NAACP members, disapproved, 8 because they felt that most of the adult midle elass, their parents, were too tied to the white power structure economically to work constructively for black equality. 9

Middle class college tudents and 5CLC' poot southern blacks took the struggle for Equality into three-fourths of our states. 10 their non-violent, direct action approach brought about a degree of racial self-assurance, confidence, and feelings of success. 11 It did not bring about total implementation of the legal victorfes of phase one. It did not bring about Integration, except among the atafis of cong and sNcC. Instead of equality, there was tokentam.

${ }^{6}$ Howard Zinn, The Nev Abolitionists (Boston, 1964), p. 167.

7 Samuel D. Proctor, The Young Nearo in Amertea 1960-1980 (New York, 1966), p. 22 .

8Ibld., P. 12 .

91b1d., P. 15 .

10James A. Geschwender, "Soctal Structure and the Negro Revolt: An Examination of Some Hypotheses," Soclal Forces, XuIII (December, 1964), 248.

$11_{\text {Proctor, p. } 27 .}$. 
The struggle for gquality culmlnated in waskington, D, C., in August 1963. The mass non-vLolent March on Washington, under the watchful eyc of the establishment, was a turning point in the Civil Rights Movement. The black man had understood the race problem as one of discrimination and segregation and had tried to eliminate both. Now he turned his attention to econchalc, social, and political opportunity. Legal rights and tokentism were not onough. 12

\section{The Struggle for Rowex}

The Civil RIghts Movenent entered its third phase as the second culninated in Washington. This phase is one of sosio-economic prescription. 13 . It might even be sald that the objectives parallel those of the anti-poverty progran. 14 The oratory for implementation of legal rights and integration is replaced with the ery for jobs, housing, and edueation.

In June 1966, James Meridith was shot from abush as he marched In Misalsaippt agalnat "black feax." The mareh was finiahed by Dr. King and hundreds of others. Before it was over, the Civ1l RIghts Movement had a rallying call--"black power."15

"Black power"--two words which are misunderstood, misused, feared.

12 James Farmer, Ereedom-When (New York, 1965), p. 169.

${ }^{13}$ David M. Gordon, "Communtties of Despaix and the Clvil Rights Movement," The Harvard Reviev, IV (Sumar-Fe11, 1966), 60 ,

$14 \mathrm{John}$ H. Wheeler, "Civil Rights Groups-Their Impact Upon the War on Poverty," law and Contemporary Rroblems, XXXI (Winter, 1966), 154.

15. Andrew Kopkind, "March Agatnst Black Fear," New Stategman. LXXII (July 1, 1966), p. 5 . 
and glorifled. The purpose of this paper is to clarify and evaluate "black power." 
CHAPTER 2

THE PBYGHOLOGY OF BLACX AMRRICA

An understanding of "black power" would be Impossible w1 thout some understanding of black people. It is with that intention that the Psychology of Black America will be discussed.

The Role of Negro"

The black man must, if raciat norms are to be obeyed, act out the role of the "1uferlor"; he must play the social role of "Negro." If a black person refuses to play the game, he ig judged by white supremacists as "not knowing his place" and harsh sanctions may follow. 1

Paychologieal research convincingly demonstrates the power of roleplaylng to change attitudes, veluec, and even conceptions of self. ${ }^{2}$ In the search for self-1dentiky the black man does what all wen do. He observes the reactions of other people to himself. When he attempts to gain an image of himgelf on the basis of his typlcal contacts with White America and the general culture, he often is shocked. The resulting confubion of self-identity and the lowerling of self-esteem, which accompany this role-playing, are two of the most sertous "marks of oppression" upon the black personality. 3

1Thomas T. Pettigrew, A Profile of the Negro American (Princeton, N. J., 1964), p. 4 .

2Ib1d., p. 5 .

3

Ibid, p. 6 . 
This confusion of 1dentity is vividly expressed in the number of times black people have changed what they call themelves, Some of their cholces have been persons of color, colored people, Negroes, colored Americans, Black-Anglo-Saxons, Afro-Amerlcans, Afra-Americans, Negro Americans, blacknen, Dlack Americans, and black peoples 4 (The terms Black Americans and black people are used throughout this papar, because these are the most recent cholces,)

The Blak andy

The black family is a matrifocal fanily, even if the father is present. This type of family 1ife has bean nurtured by slavery, migration, conomice, child raising, ${ }^{5}$ afd to dependent children, and a job market more open to women than men. ${ }^{6}$ Women are most secure when they manage fantly affatrs, If the husbands or men are outside the famliy strueture, the vomen often live in three generation natriarchial homes where grandmothers care for their daughtexs' legitimate and 111egitimate ch11dren. ${ }^{7}$ If the husbands or men are 1iving with thelr families, they have 11ttle eredt with their women to tide then over periode of unemployment. Men, who do not bring home money, are not worthy of any wifely comitments. 8

${ }^{4}$ C. Eric Lincoln, "Color and Group Identity in the United States," Daedlue, Spring 1967, pp. 533-34.

5ptefgrew, pp. 14-15.

${ }^{6}$ Le Ralatater, "Crucible of Identity: The Negro Lower Class Fani1y," Daedlue, Winter 1966, p. 179.

7 Ibid., p. 199.

${ }^{8}$ Ibld, P. 192. 
Children are exposud to set of experlences and a rhetoric which

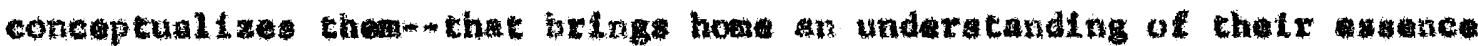

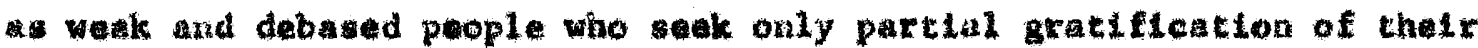

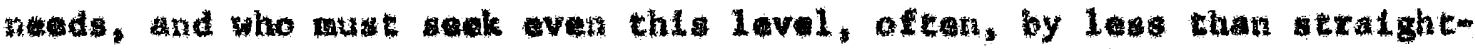
Corwaxd means. 9

The black heme is often broker home. Only thre out of four have both parent prosent. This compares with nine out of ten white hease. Fenulen, without mates, head 21 per cent of all bluek tamilles, while malew, alone, head 5 per cont. Onembixd of all black chlidren under the age of thirten live in howe with only one parant, comparad to one-tenth of all whte premtem. 10 Weak egos, among black adulca, aro traced to thla samily dLorgantgation. 11

Placks sed the world as hostle and threatening place-- they expect violent mistreatant and heve tealing of atter helplessnema 12 To those Ifving in the hearta of the ghetto black comen to woan not juat "atay back," but almo memberahtp in a comonuty of peraon who think poorly of exch other, who attack and manipulate exch other, and who give oach othor mall comfort in a desperate world. 13 stokely Carnichael, "black power" advocate, put it this way--Black America 10 tho whita man's colony, held in thrall by 1 ta fear of the waster elase and by 1 ts

9tbld., p. 206,

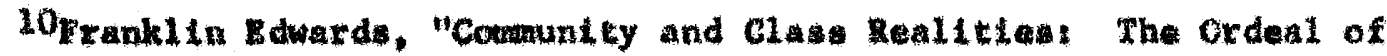
Change," Dagdius, Wnter 1966, p. 8.

${ }^{11}$ pettrgxew, p. 23.

12 Ibld., p. 11 .

13 Ralmwater. 205 . 
paraly ing doubte about 1tede. 14

The black man, the male, has been victialed the mot, If he does what Awerlean society denands of him--narrles and hes forly-he exposen hiwself to the very real danger of faliure. 15 the wen who

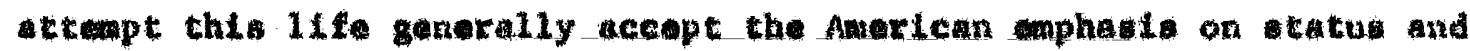

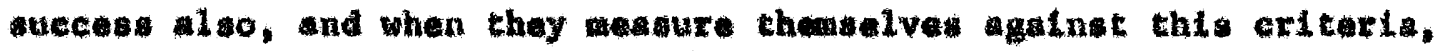
they come up lacking. 16 Many men find lt better to be juet "the boy" triend." They live in flop houge, institutions, or girl-trtends" howes. 17 Bestdes the impacts of the role-playlng, the matrifocal family, and their soclo-economic otanding, there are two other phenemena whieh have been augeated as adding to the total wale selfconeept in a negetive way. Onw is the chrletsan chumch and the other Is the "taboo of the whte woman." David T. Bazelon belleves the southern Christian Chureh is "domfnated by women" and "Intused with thele puxposes and nowd" and thut this holps to confunt the wale role. 18 If Bazelon is corrack, thi is very ignificant, atnce the church has always been the backbone of the black comuntey in the wouth. The other phonomenon, the "taboo of the white voman," fa discupsed by Calvin C. Hernton in hi book, sox and Racign. Tht to whe he has to ay: "The taboo of the white wowan eate into the pwyche, erodes away

14"Which Hay for the Negro?" Leweek, IXIX, May 15, 1967, 27.

15.

16 pectigrew, p. 9.

17 Rainuater. 199.

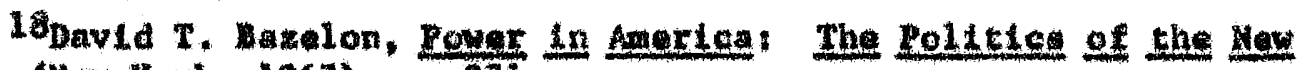
Clage (New York, 1967), p. 271 . 
algniflent portlons of boyhood sexual developmext, alters the total concept of masculinity, and ereates in the wegro mala hidden

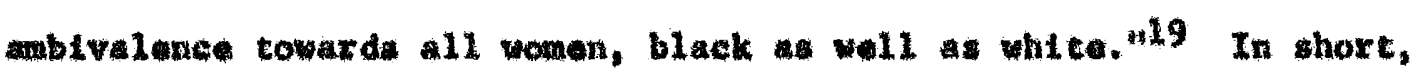
the black wale has been danied his agaculinity.

\section{Summary}

The effect of playligg the role of the Inferior are profound and lagting. "gvaluating himedit by the wy othera react to him, the Hegro may grov into the servile role: in tue, the person and the role becone Indiatinguighable. The personality consequences of thi whution can be devastating--contuation of self-1dentlty, lowar self-entewn, perception of the world a hostle plece, and nerious aex-role contricts. $* 20$

The struggle for Legel Rights, The Strugele for Equality, and tho Indopondance of fomer Afriem colonlas, whore blaek wan now govarn theaselves, polnt to worth in the black race, the race which has known. notbing but infezloricy. As wo ned anliar, as black mon became Involved in the Civil Aghts Movent through non-violent, dizect action, they developed new fealinge of racial self-assurance, confidence, and euccese. As black men look thetr own success, 1imited as it is, and to the success of the Africans, the old wounds of contused Ldentity and danaged welf-actem are beglnaing to heal. 21

\footnotetext{
p. 58. 20 pettigrew, p. 25 .

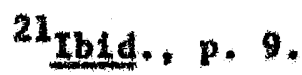

19 Calvin C. Hernton, Sex and Eaclen in Amerles (Garden City, 1965). 
CHAPTER 3

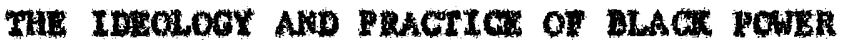

The phllosophy of black power to to bring about aquallty-not jute equality of opportunity. . Old taetich have not worked. 1

Dr. Nathan Hare

Black power does not wan the ovarthrow of white power. It ta not atter of replacing whit power with black power. . We do not atrive to take over. Wo Just want to be right up there on an equal plane--elther separately or integrated ox by any mane..2

Dr. Wathan Hare

W. must organize not only anong ourselves but with other groups in ordex that we can, together, galn power suffictent to change this natton" sense of what il aos important and what muet be done now. 3

Wational Comitte of Negro Churchen

Oux coneern for black power addresees 1 tself directly to thi problen, the mecustcy to reclatm our hiotory and our tientity from the cultural terrortera and depredation of ch-juatfying white gullt. ${ }^{4}$ stokely Carmichacl

Black Powex: The bringing rogether of blek people to alect reprementatives to work for our neede.s

stokely Carmichnel

I" "Black Powar"m-Itg Goals and Methods," Aport, ixIt (May 22, 1967), 65 .

2tbid., p. 66 .

3"Dlack Powers statement by Nutional Comitte of Megro Churehnen," The New York Tines. July 31, 1966, p. B5.

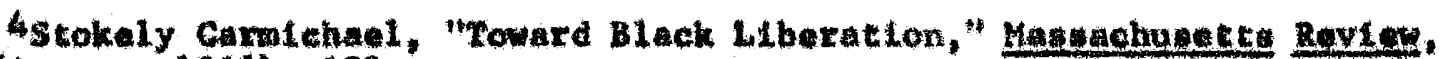
VII (Autumn, 1966), 639.

Sgtokely Curmichael, "Black Power," Phonotape Huber 600, Portland state College Library, Prtland, Oregon. 
Contro1 18 what we working for. It we lack mortky, then we souk our righeful shar of control.6

Stokely Carmichal

Out nettlesme task to to dincover how to organlte our trength Into compaling power so that government cannot lude our demands . . scic must now undertake mastive job of organization to gatn economie and polltical power for Vogroes. 7

Matein Luther King, Jr.

Mlack power is nowviolent economic and polltical powar axerctacd by and on the bahalt of the Hages 8

Dr. Nathan Vright:

We are not retormers. . We are revolutionarles. We vant to change the Amexican rogtme.9

Itokely Carraiehal

We've been maktng men out of Nagroes-men who aren't afratd of howkte wether they are vearing shote or

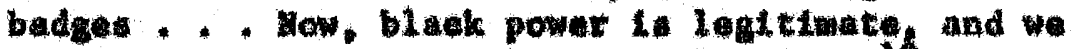
can bagtn to chillonge wht tnateitutions. 10

Stokaly Carmtichad

"Black power" is Amertce" most mismuad metaphor. 11 What doas it

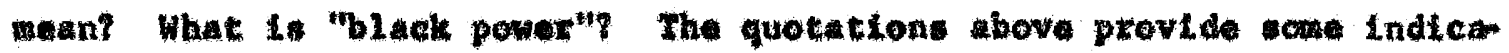

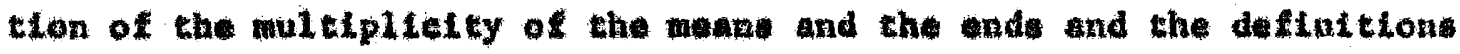
of black power. There is no one gpokeman to who we curn for an explanation. There 4 no one orgentsation to whow we can turn for the defintion. And more importantly, there in no "one race" united in a

\section{xpld.}

7whtch Way tor the Nagre?" p. 33.

Bartin Arnold, Muark Meeting of Black Power Attanded by 400 ," The New York Timge, July 21, 1967, p. 34.

9"Garmichmel' Activitien," Iacto on L1L. XxVIT (Septembor 14-20, 1967), 397.

10:Which Way tor the Aegro?" p. 30 .

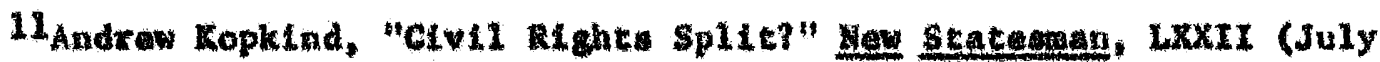
15. 1966), 75 . 
"Blueprint for Action" to whow we can turn. "Black power" has different meantrge for different black poople, butesentially it in aolution. a black man's molution, to and mecond class eltzenohip. Black pover in a rallying call, but it is not just alogan. It is "Bluprint for Aetion."

According to Leonard Hroce and Norval D. Glenn, there are three types of wovenunte In wheh "nationalist" groups can engage. They are cultural, econoute, and pollttent.12 the degree of "mactonallem" in black power will be conaldered and aviluated in the next chaptex. At this polnt, 1t in suffietme to say that bluok power does indeed addrew 1talf to eultural, ceonemic, and polltical goale.

In July 1967, Dr. Nathan Wright, Jr., Emecuclve Director of the Departuent of Urban Werk, The Eplecopal Diocese of Nevark, Nev Jeraey,

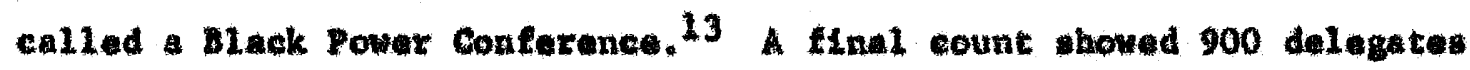
representing thirty-alx states, forty-two eltles, and 197 organizatlons.14 some delegeres repremented the ratitanta from Us of Watts, Harl 's Maukau, and the Organtation for Afro-Amexican Unity, which wa Loundad by former Black Mullin, Malcoln $X_{*}$ othar delegates represented coke and smce, the beet known attonal black power advocatIng organiationa. It in vary tmportant to note that representatives of ScL, the NAAC, and the Urban League were in atcendance and participated in adopting black power resolutiona, The latade of then

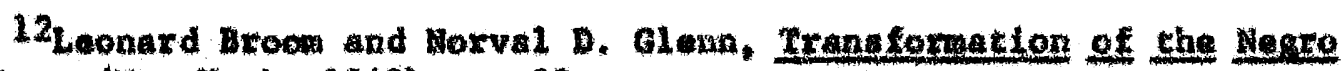
Amerlean (Now York, 196s), D. 38.

13Arno1d, p. 34 .

14Thoma Johnson, "Negroes Disupt Newark Rarley," The New Xork Imee. July $23,1967, p, 18$. 


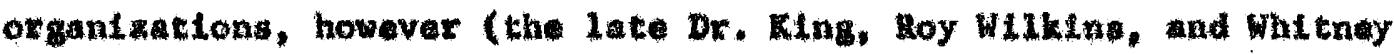
Young), vere notably baunt. 15 The rasolutions of tha confermen, Which should be reprosentmive of the present mood of Black Amertes, and stated goals of cone and stoc, or their spoketmen, w111 b* utilixed in dicuselng the cultural, aconomic, and political goals of black power.

These cul tural, economic, and political goal are outlined below. Som of the objectives have selt-evident means for realtation and Lapleaentation, otherg do aot. Examples of woe for black power, whlch hove been suggested and/or practloed, are lacluded in the diacussion.

\section{The Cultural coals of Hack Rower}

Bagteslly the cultural goul is for unity-mall black poopl involved with weh other in thought, woxd, and doed. In oxdex to reallze this

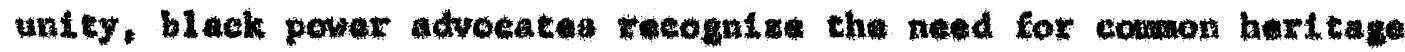

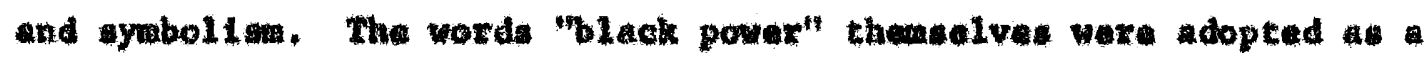
symbol of unity and alf-help.

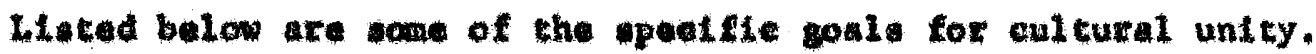
Som are explicitly tied to the mans for Implementing then. Other. are not.

1. The extablithant of euleural tes with black people of the vhole norld, 16

2. Black poople detextning for thmoelves the coursus of acton they will teke coward gatning "real power." 17

15. Arnold, $\mathrm{e}, 11$.

16"Coals ouelined for Cont Heeting," The Nev York Itaeg. June 20, 1967. P. 25 .

17 tbed. 
3. The developent of black leadarship and postive selfImager 16

4. Countaraction of the sense of infertority and insuffictency. 19

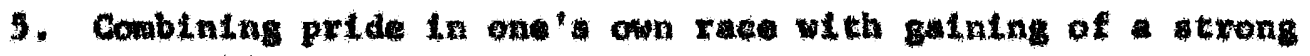
pouttion for bargatndig-mor reprianl. 20

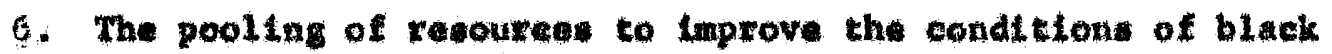
paopla. 21

7. The establishment of black univeroletes to make profesalonal black revolutionarles out of revoluthonary black profea lonal "22

9. The astabliabuent of bleck national hollday to houof black hatroas suab as Nalcoln $x .^{23}$

4. The beghaning of ational dialog on the deatrablitey of

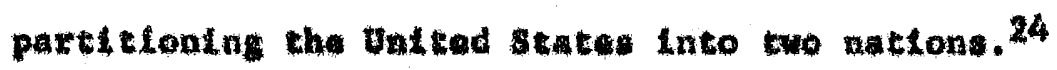

10. A boyeote of publication accepting dvertiging for halx atralghtonere and bleaching oreme. 25

\section{${ }^{18}$ ibed.}

19"Raci in Revarae," Econgatat, coxx (July 16, 1966), p. 261.

20iriack Pover Play," Eeonomiat, caxx (July 2, 1966), p. 39.

21 "Black fower at the Polls," Mbony, wIII (January, 1968), 25.

22"Black Power Conterance," Iagte on 11e. WryI (August 3-9, 1967), 314 .

23 Ib1d.

24 Ible.

25 Tharsa A. Johneon, "Boyeote of pporta by Negrow Aked," The rew York rimeg, July 24, 1967, p. 1. 
11. A boycot of the olymple ganes and profenshonal boxing. 26

12. boyeote of black churchen not comalted to black ravolution. 27

There 1 avidence that the gold wtated above not just words.

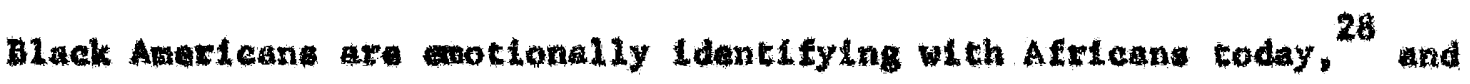
tho event of thei ancemtral home are important and meaningful to the. 29 The "natural black, "wo shunk hate strafghtener and blenchlng

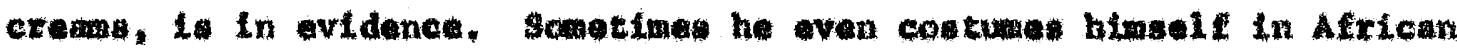
garb. Many black athletes are boycotclag the olyaphea. Thexe in a call for and tamehing of black hlatcory and black languages. Black atudent Unions are belng organias In prodominantly white univarsteloc to establish 1 lake between the ghet to and the university. 30 Frequently we heat and read the klogans, Black is Cood and Black is Beauti zul.

The ned and the deglre is for "black awarevese," the goal is unity. Dr. Wright pute 1t this way, "Unity does not mean concensus.

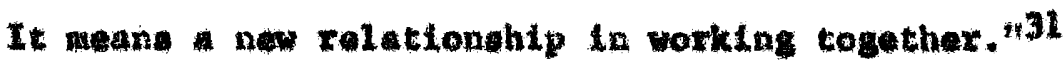

26"Black Power Conference," p. 314 .

27Johneon, "Boyeote of Sports by Hegrow Apked,"p. 1 .

${ }^{28}$ samul lubel1, Whtte and Blagk (Mew York, 1964), p. 42.

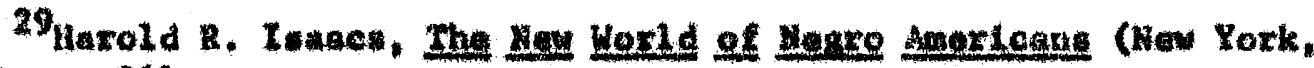
1964). p. 261 .

30 Ernest Dunbar, "The Black Revolt Hits the Whit cabus," Look, xxxI (October 31, 1967), p, 29.

31. Anno1d, p. 34 . 
The Econoule Goals of Black Dower

The economie gols of black power are concerned with ralsing the tandard of 11ving for blacks. Even chough the majortty of the povertyatricken In the UnLted states are not black people, the majortty of black people are poverty-stricken. 32 They represent one-tenth of the cotel population, but one-fourth of the nation's poor. ${ }^{33}$ Hore than one-halt of the Emiliea live on leas than $\$ 5,000$ per year and onefourth on lews than $63,0000^{34}$

Ineone, however, if not the ontire story of theit poverty. Black are genarally propertylews. The coat of conoumer durables on eredit to more for thera. Their woney doesn't buy mach housing as whit money does. Black poor temily olze averagea one-half chlid more than the poor white tamily. 35 Most live in an urban setting whare governaent projecte such as urban renewal often hure rather than help thea. 36

Huployment is the bate need and unduployment the bate problem. The Black Aatericen has betr dieplaced by the farm Into job market for whlch he it not ready of qualified. 37 The wechanization of the farm he

32 Wiehael Rarrington, "Introduction," in Poverty In Amaticu, eda. Loula A. Forman and othere (Ann Axbor, 1965), P. Xix.

3 Taxmer. $_{\text {p. }} 170$,

34 Piven, p. 20 .

35 Alan Batchalder, "Roverty: The spectal cane of the Kegro," tn Poverty In Agerica, eds. Woul A, Formen and other: (Ann Axbor, 1965), 1. 113.

$$
\begin{aligned}
& { }^{36} \text { zbid., p. } 114 . \\
& \text { 37 Edwards. . } 3 .
\end{aligned}
$$


Left 1 matched in the efey by the autotation and decentralization of industry. ${ }^{38}$ He 1 unable to find stedy work; he ia the 1 ast to be hired and the tirst to be fired ${ }^{39}$ More than anything else black people want jobs: Black power addresses itself to this need because it recognizes that in America the primery source of individual and group identity is mploymont. ", " what you do is what you arei to do nothing is to be nothing." 40

In order to ralie the black etandaxd of living, black power suggeats the following goals:

1. Obtain federal poverty noney to be uaed by and for blacka, 41

2. The establighaent of black financial institutions to provide housing and bustiness loan to nelghborhood black credit unlons 42

3. Guaranted annual income tor all ctitzene. 43

4. Selective-buylng pregrams, including natonwlde "buy black" effort. 44

5. The establiohnent of black housing and bullding cooperativas 45

6. Full exployment.

38 iven, p. 20 .

39 Batchel der, p. 117 .

40 Moynihan, p. 746 .

41 CarmLchael, "Mlack Powar," Phonotape.

42"Black Rower Conference," p. 314 .

$43_{\text {zbLd: }}$

44 Ibid.

45 Ibid. 
7. Job training.

The Black Rovar Gonference adopted revitution threakening to ditrupt the natlonal concmy, th thare is no action for guaranted annul income. The conforence al so stated that balective-buylng and

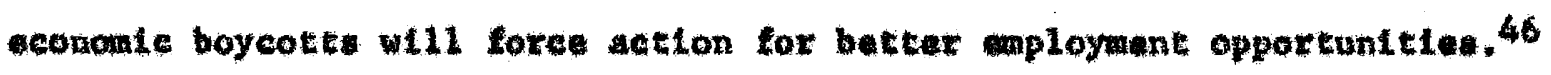

Again we note that acne of the poels, as stated, have the vehicle tow taplementacton bulit tin, whil othere are vague as to how they will be achtoved. There is seme ovidune of activity, howover, in support of of In implenentation of these solis.

cons, under the direction of Floyd Maxisatele, has been very active

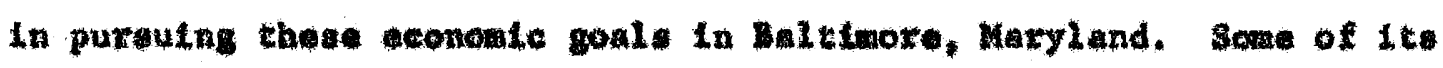
projecta have boen auccaseful, ouch a a leased filling ctation to train drop outs and Maryland Freadom Union which won bargaining tight for three retull storen" hloyees; and some have not been

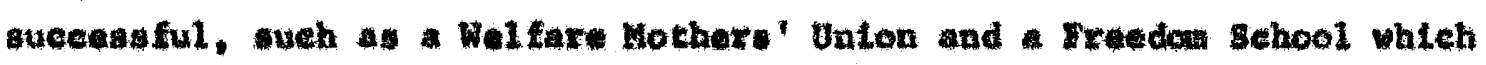
oftered conouner buylug advice. 47

8c.c. under the laderahtp of the late Dr. KIng and Rev. lalph D. Abernatiby, way activaly involved tu the garbege collectors union"

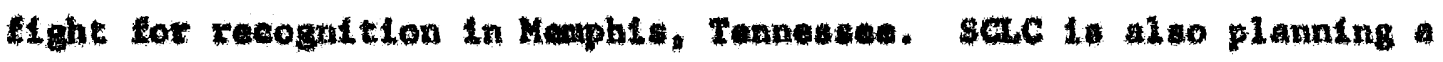
warch on Wamington to bring national attention to the needo of Anertea' poox.

The Polltical Goal of Black Powex

In politles, Back pomer ment Indapendent action-wegro

${ }^{46}$ rbat.

47"whleh Way for the Nagrot" p. 30 . 
control of the politieal pover of the black ghattos and 1to consctous use to better lum dwallexs conditons, It could take the form of organtatng black poiltical parky or controlling the politicm 1 machinery withtn the hetto wthout the guldance or support of white pollticLans. Where predominantly legro areas lacked Hegroes In elective office, whother in the rural Black Helt of the Bouth of in the urban conters, Black powex advoeates sought the leetton of Wegrow by voter zeglatration campalgne, by getting out the vote, and by working tox redrawing lectoral districts. The bale belief wat that only well-orgnulaed and cohestva blos of Hegro voters could provide for the neade of the biack mages. Bven some Hagro polltielans llied te the major political parties adopted the term 'Black Power' to deseribs their interest in the Negro voto. 48 National Adviany Comiastor

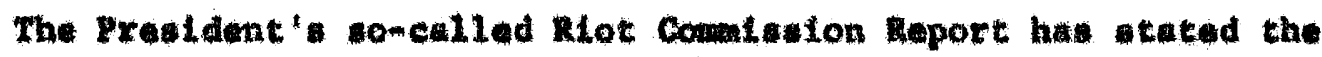
black power political posttion quite aceurately, except tt pute 10 in the past cenge. Black control, bloe voting, and bluek partis are current inewed. not hlatoridal ones.

stokely Caratchael, past chaimuan of succ and probsbly the beet known and moat quoted blaek powar proponent, belleves the "kny to selfdatermination is polfctcal power, ${ }^{\text {4h }}$ Hit deftaltion, that was noted eatliar, states that black people should unite to lect representatives to work tor black people' nesds. In the past black people have looked towards the major partie for representation of theit need .

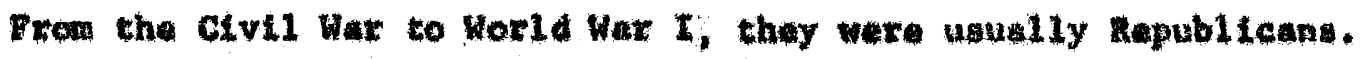
The docade after World Wax $I$ wa naxked by major developent. The black soldier returned tron the war Aghting for democrecy and freedow at home, but Republican Prestdents Hazding and coolldge did not

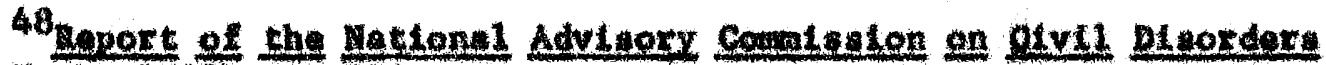
(t) York, 1968), P. 233.

49 carmbehael, "Black Rower," phonotepe. 
respond; and black began laaving the party of thalx LLberator, Abrahew Itacoln, to becone Democracs, 50

Bven though he was accused of "playtng both bldes (north and aouth) against the middle, "Franklin 0 . Roowevel and hie Now Dal completed the Denocratic Party's capture of the black voter. Roosevelt was particulurly popular with blacks because be had porsonal friend: who were black and because he browgt black wpeclaliats to wambington as alde and advisor to major govornement departments. 51

Prestdont Harry Truman was not a popular with blacks as noosevelt, bat ble executive ordar of 1948 ending agregution in the amed ferese wa consldered major victory and kopt black taithlul to the Democtatic Party. 52

Blacix Amerter did not choose President Dwight D. Eisenhower, Republican. They expected 1ictl of him at fixst, but because of the "revolution in expectationo," his popularity rone frow 22 pex cent black suppore in 1952 to 40 per cent support in 1956. In 1958, he wor additional support when the Aret Ctvil Right B11 in alxty years mas pasoud. 53

Thus In 1960, both polttleal parties, recogndalng that Black Amertca vas in "revolt" attempted to woo the black vote. 54

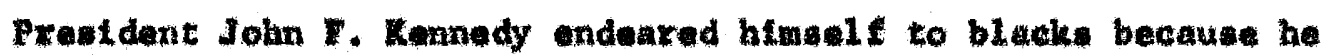

50, Loule 2. Lomax, The Nence Rovolt (Now York, 1962), D. 225 .

51 Lb1d., vp. 226-227.

52 IbId. p. 227 .

33 Lide., p. 228 .

S4lonax, 228 . 
provided paople with the tools to do things for themselves, 55 and because he suggested and aupportad voter reglatration drivan. 56 His death was a shock to fll Amechans, but Black Anorlears secaed to feel the loss more keenly. They were undure of what to expect of the aoutherner who auccended to the preatdeney.

When that same southerner, Frealdent Lyndon B, Johnson, ran for ro-alection in 1964, he was overvhelmingly supported by black people. He reentved 90 per cent of thatw vote. 57 prestdent Johuson has pushed through Congrese more civil righte leginlation than any Presidant in hibtory, but, beceuse of the Increasing racial wreat in Ameried, there Is no guarante that blacks will continue to vote the same Demovratic ticket.

Local, tece, and national alectone, eapectally anee 1966, Indicate that notther party ean be mure of the black vote. Black people are going to auport candsdute and programe that aupport theo.

Spectelcally the poltetcal goals of black power are:

1. Control or rlghtud shrwe of control 5 th

2. Black polftielane repreanting black counand tea, not whit te downtcown machlnery. $\$ 9$

55 zbLd: 239 .

56 Ibld. p. 232 .

57charles F. Tager, "Powell and the House: A Black Rower Vketory" The Chriation Century, Lxxxy (February 8, 1967), 175.

58 Camichal, "Black Rover," phonotape.

59 Ibld. 
3. Open political action wheh 1 partisan and diract. 60

4. Creation of third politieal force or party to wid a balance of powar. 61

5. Control of loeal school boards which terve black communtites. 62

Black polithletana of the past have been vote deliverers, mosty

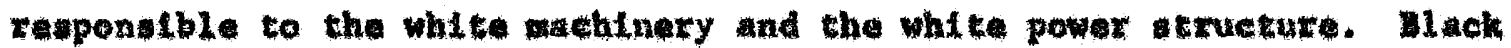
powar labits upon black polltichans betng responatble to the black

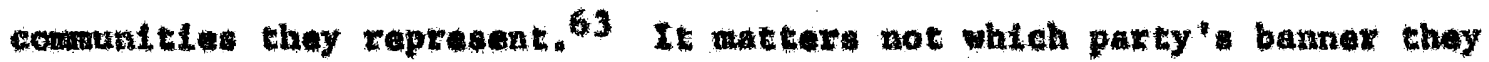
earry: it matter ony that they are raceptive to black needs,

In wone areas third party bae been organfed, wah so the

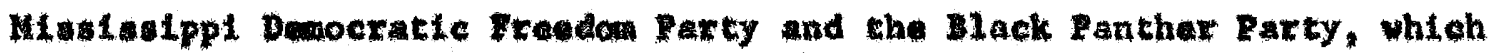
1. active in several statas. 64 Thexe are many other axamples of black politicl power at work. two are aned below.

In Callfornta the Black Student Ontor of San Franciseo State Colleg helpod galvante an apathette black axe into electing black

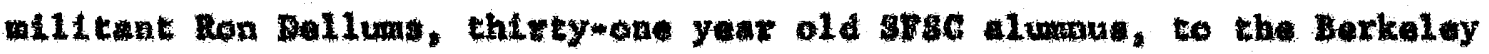
city counet1. 65

In Onto Blacks mounted what may becone "textbook oxanple" of bleck power. Black peopla sav a chance, moved in on $1 t$, supportad and

60 marner, p. 181 .

61 Jobneon, "Woyeott," p. I.

62 Carmichal, "Black rower," phonotape.

63 Camlehael, "Toward Black Ltberation," p. 649.

64 Carmatchael. "Black Pewar," phonotape.

65 Dunbar. B. 30 . 
controlled it 11 the way, and were maxt onough to get whatever help was necessary to vork every detall of the campaga for mayor of cleveland to thate ow advantage. The clty was "on fire" with black-bloc

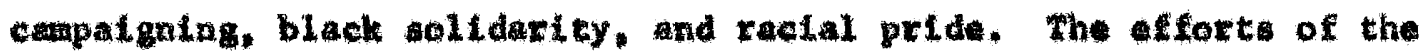
locallties, coke, fand Dr. Kung rasulted in the election of carl $B$. Stoke. 66

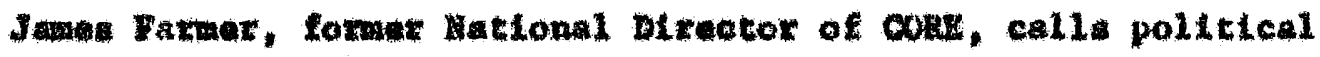
action wethod of welk-help.67 Voting reglatration statitics indicate that other bleck people agree. In 1940 omly 250,000 black were regletered to vote in the south. By $1966,2,620,359$ vera ragtatared.,68

\section{DLek Power and Vtolance}

The woot quoted black power gdvocatew In America have bacome Ineroatngly milleant. Thls, of courae, has linked black power with violence. The two teme, black povet and vlolence, have becke ynonomoua to mont of White Amorten and ever to some sogmenta of Alack Amerion.

stokely Carmichat has bean quoted sayingt

"If we dan't gat change", are going to toar thla country apart. 109

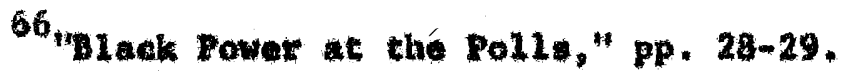

67 Taruax, 192.

68 Reese Cleghom and Pat Watcer. "The Impact of Nogro Voten on Southern Folttice," The gexorcex, Xxxir (January 26, 1967), 24-25.

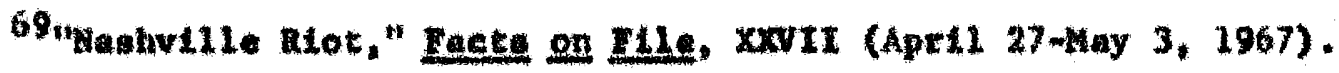


Auguat 18, 1965 to the black "day of independance." (Watta) 70

"ro bell with the lave of the Untted states."

"Hota are "rabellion" whtch need not be apologized for," 72

"If honky trion to shoot you, k111 him before ood gete the news. 73

Adam Clayton Powell, fomer Congreaman fxom Yoxk, tolla blacks

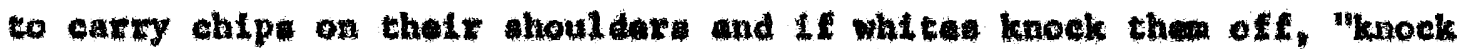

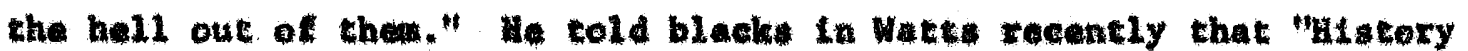
1. gotng to rocord thet the aceond Civil uar and the beginning of the Bladk Rovolution wa born hore. ${ }^{174}$

H. "Rap" Brown, preount chatranan of swce, couneals blacke to arm themselves becuse whites are thet onemies and 11 chey (whites) underatand to guns.75 Mis othor coments inelude:

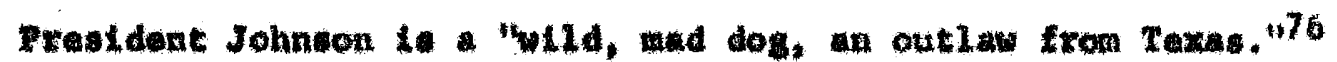

"There should be more ohooking and looking."27

"It Hahington, D. C., don't come around, Wathtagton, D, C..

70"caralehad " Aetivitide," p. 397.

71 "Which Way for the negro?" p. 28.

${ }^{72}$ rbid:

73 ibld.

74"'Powell in callfornta," Recte on Z1Le, wavix (Jantary 11-17, 1968). 12.

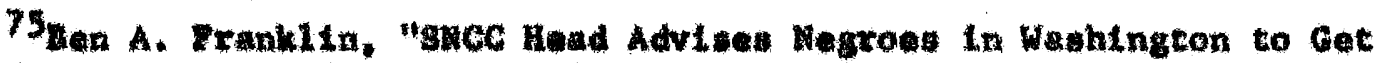
Gune," The Yor York Iige, July 28, 1967, p. 14.

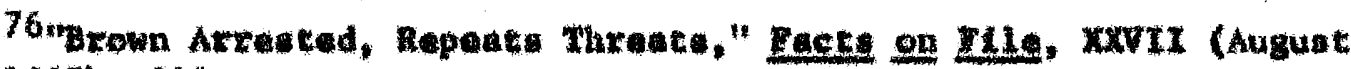
3-9, 1967), 316 .

77 rbed. 
should be burned down." 78

"I say violence is necessary. It is as American as cherry pte. 179

LeRol Jones, black playwright, has written Dutchman, The Tollet, and The Slave with the theme: To be black In America is to be revoluthonary. Hatred, venom, brutality, protanfty, and downright Insanity are turned back towards the wht tes, from whence Jone belleves they eame. 80

swce endorses the 1 dea of guerrilla warfare and regards violent civil dieorders as rebellions. CORE la less militant and edvocates vlolence only in self-defense.

The axtent to whleh violence is approved by black people and used In pursuit of the goals of black power w111 be discusaed in Chapter 4.

\section{Sumnary}

This has been an atteapt to elarify what black powar $1 \mathrm{~s}$, what it is dolng, and what it hopes to accomplish. The words thenselves serve as a rallying call for blacks to unito and for blacks to help thenm

- velves. But black power is not just a slogan; it is a mood, a movenent, a solution. There is no one organization or pergon to whom we can turn

${ }^{78}$ Ibld.

79 Ibld.

${ }^{80}$ Calvin C. Hernton, White Papors for White Americang (New York, 1966), p. 144 . p. 234 ,

${ }^{81}$ Report of the National Advisory Commisgion on Civi1 Disorders, 
for explantion and clartiteation of the ldeology or practice. But rentakch Indicates that black power addresses itael to three types of gol. eultural, ceonomie, and polttleal. The baste cultural goil is

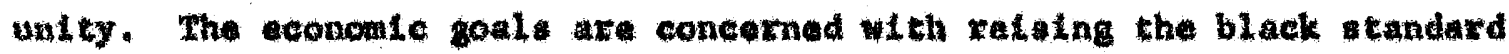

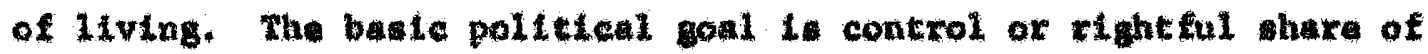
control. 
PART II

THE EVALUATLON OF BLACK PCWER 


\section{GLATIER 4}

THE RVALUATON OF BLACK POWLR

word Acton' princlple that "power tenda co corrupt and absolute power corzupt absolutely" is a grose overalmpliftcation of the facts. Power dees coxrupt, but it al oo cun annoble. 1 The foundera of Amerten dewocracy would have disagrewd wth tho statent and agread with Lord Acton. They followed the politicul theories of James Harring* ton, Charlos L. Montesquieu, and John Loeke by writting and adopting a constetion based on the divioton and geparation of powers. haricano did and do wupect power and expect that it necmosarily leads to cormuptlon. Wo fall to realize that "retitude and power depend upon context, upon vartous tactor-comblnationa in peranallty and mactecy."

Even weh the ingtitutlonal gafeguard. agating power and the coupon ditrrut of 1t, Anartea has developed political system which t.

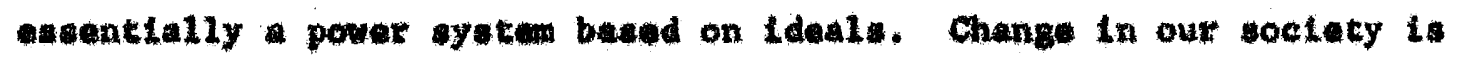
detinad as prograsa towards those 1deals. Kenneth B. Clark, paychologi:t and sociologtat, states, "the new American Dileam to one of power. The dilenan is a confrontacton between those forces which trapel a actety to change and those which sook to malntaln the past." 3

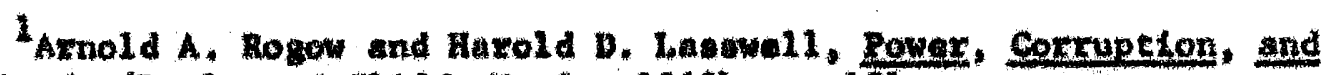

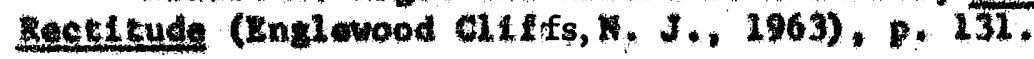

21bLd., p. 65 .

3Renneth B. Clark, "Introduction: The DLlene of Power," In The

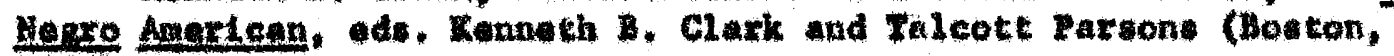
1966), P. X. 
John OLfver K\$1Lens, black author, has wricten, "The Negro lovea Amartca enough to criticize har fundamentally." 4 Back Arericans do

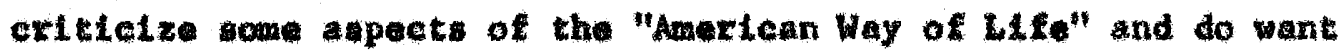
changen. They have exied to "impal aoclety to change" during the firet we phases of the Civil Righta Movenent. They flrwt tried the legal approach of the MACe and then the direct action, non-violent approach of cont, swce, and the solc.

Blecks undarstand that in thlo change "paln and progrew are

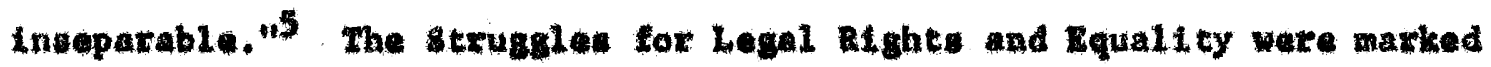

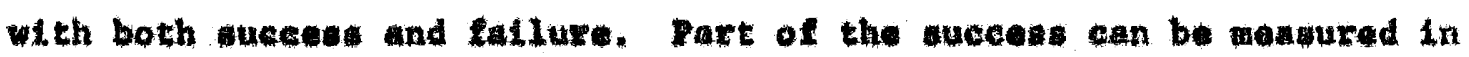
a by-product--pouer. As they voxtced together, they gatned pover. And as they gatned this power. they gulned a measure of troedom, which is

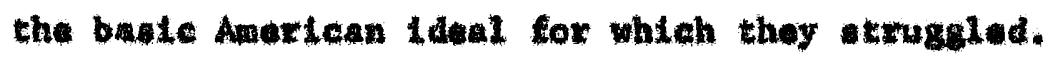

The mensure of the lack of freedom is the lamk of power. Prior to World War II the best wore to deaertbe Hlack Amerien was "powerlasa." They wex alwo not Iroe in the traditional Amertean conept of the word. Thay were not allowad to "do vhat they vanted to as long as it didn't Interfere with another' righto." The alave is recognizable by his Inabilfty to act and to cauge othar to act. The free wan if one who hat power to act and cause: other to at. Freedow then conotits, not in the nation, but in the use of power. 7

41111 B. Hixeon, "The Ragro Covolution and the Intellectuala,"

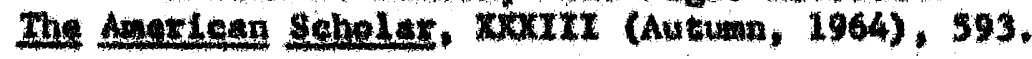

Sowax, 100.

Gadd, p. 18.

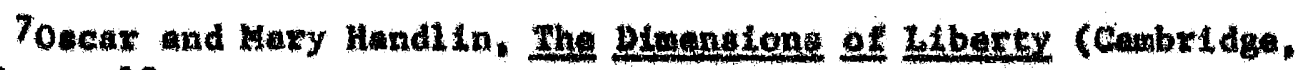
1961). P. 18 . 
Rower--the very wed of ten bringa catcional reactione of fear and diatrust. Black power-me vary vords do bring thes emotional remponses to White Anoxleans. They do not realitu that black power.

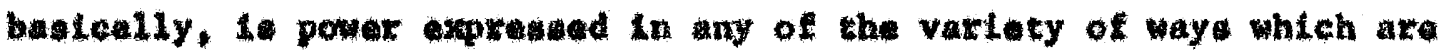
comon In America! in poltetes. In the economy, and in dmple and effuetive means of alocacton.

In elaxtfylag the coneept of black power, the recent atrugeles of the Givil Right Movenut were deseribed, the poychology of slack

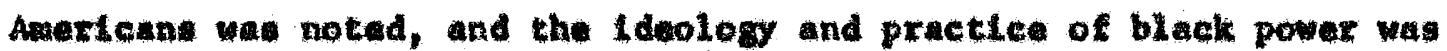
discusaed Ln objective manner possible. It reatio now to evaluate thit phenomenon "black power" by aneverlng these questions:

1. Why bleok powet and why now?

2. The group ox individualisan?

3. Integracion of ceparaclem?

4. VLalence of non-vialencet

5. Are the economic and polttical goale of black powar realistic?

6. What are the organisationel nesdet

Why Black Powar and Why Now?

In 1964 Jane A. Cecchonder publithed a paper entilled "Soelal Structure ad the Wegro Revalt An Exatnation of sene Hypotbesas." Wo of the hypotheses, which he axemined, he rejected. Three vere

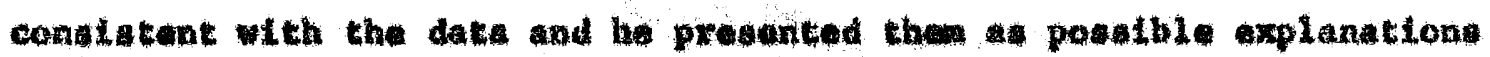
for what he called the "legro sevolt." The thre plausble hypotheser 
are discused balow.

The RIsing expectation Hypothesis: An a group experiences an

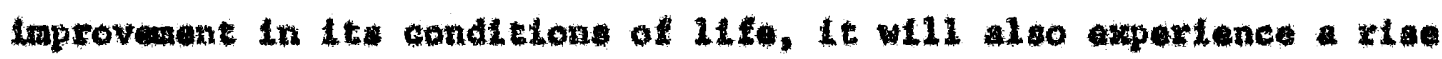

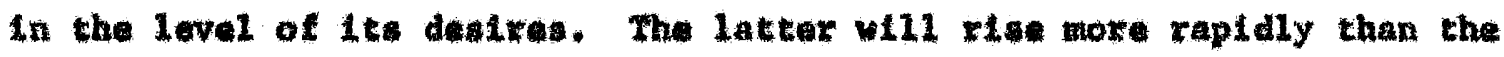

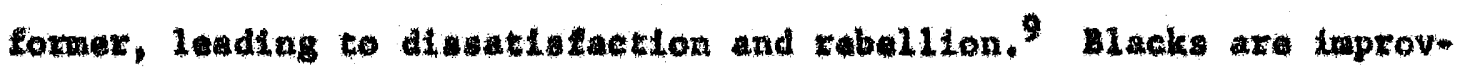
ing their posttlon adweationally, oceupationally, and concmalcally. 10

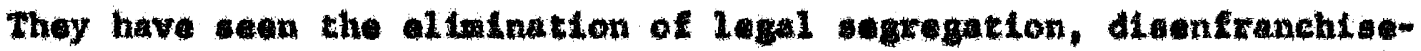
went, and official brutalley. ${ }^{11}$ All thle reoultiod in an increase in axpectatione.

Dut this "rovolution in expectations" hes not been accoupanied by an equal measure of improvenent in the conditlon: of 11fe. canerally, blacks have been auked to aceept tokmint ma.

The Relattve Deprivation Hypothesi: A a group expexiences an Improvment in $1 t$ condttons of 11 fe and simultaneously observes

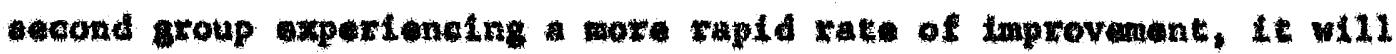
become diebatisfied with 1 te rate of Inprovenent and robel. 12 Income data are Indicatore of the vallaty of this hypothesie, White lncowe L. Incramatng more rapldiy than black tncome. 13

The status Inconolstency Hypothest: A group which posseases a number of statu attributes wheh aru differently ranked on the various

\footnotetext{
Qeachwender, p. 249.

10 IbLe.p. 253 .

14 Kopkind, "Civil elghts iplte?" p. 75.

${ }^{12}$ Cosemwender, p. 249 .

13 Ibld. F. 254.
} 


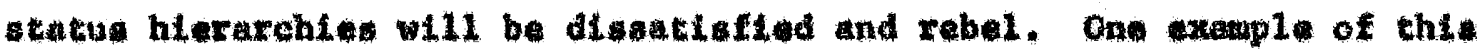

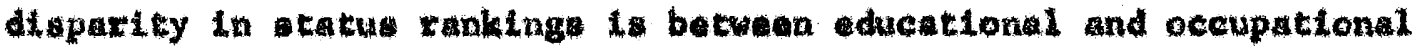
chievenent. 14 Black are improving thetr ducational qualification fox pxotesslonal and technleal fob more rapldiy then they ara recelving thase jobs. 15

Dr. Ceschender" thre hypothases appent to be valld ones. Ho did not ehoone anong then of place then in any hierarchieal ordor. The

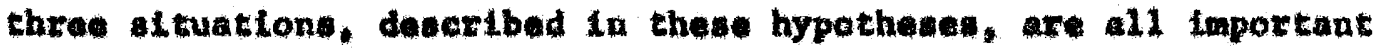
conaldoration in waluatiag the racial oftuation in the United statea. All thrae help to explain why Black dmertad has moved into a third phave in the Civil Righte Movenent, the struggle fot Power. The firet two phases produced the altuationa descrtbed by thmse hypotheses. Phase three, the struggle for Power, to the result.

But why strugste lor power? It vas noted earlion that part of the wecess of the direet atton phase of the novenut wa the by-product, powar. Power achieves results. Rowerleas Black Aremica had to alk for 1t: Ightful Inherltance, becauce it had no power to take it. It had higher expectatione than the dcalnant white pewer atructure vas of is

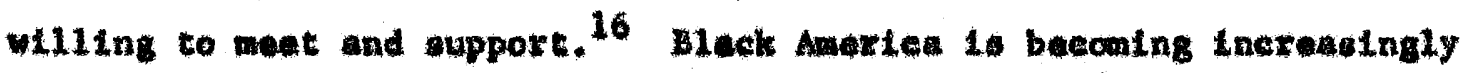
arane of the value of powex in achtoving the vocto-ncononic afms of the Civ1l Rlghes Hovement. Blecks, generully, have coneluded that White Awartea he done all it is golne to do. Thoy ay it is tine Black

\section{Ibld. p. 249.}

15bid. p*254.

16 Woman Jaclaman and Jack Dodnon, "Negro Youth and Diract Action," Phrlon, XxvIII (Spring, 1967), 15. 
Martea does what need to be done to take ito rightul inheritance. The struggl for Powar, black powor, I the result.

There are two other specte which should be considerad when atceapting

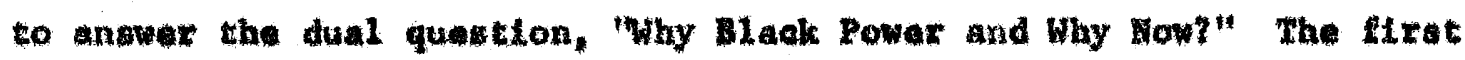
1. the Kar in Vlet and the second is wht could be called wale andereton,

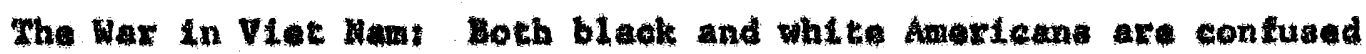
bout the var in Viet Man. Many feel it i. an unjust, Lnoral Amorican undartaking, whlch is dratning thic country econoutenliy and physically. Other: feel that Anertea has legal and moral obligation to ba milltarliy inwolvad ta thla war, wo meter whet the cont. Blacke protent aguine the war in bout the same proportion as whtee, but they are opposed for raetal a vall a legal and noral renona. Theae ractal resgons axe (1) it Ia unjust to be ekked to fight abroad as long as they are recetving leas then a full moauro of onclal and

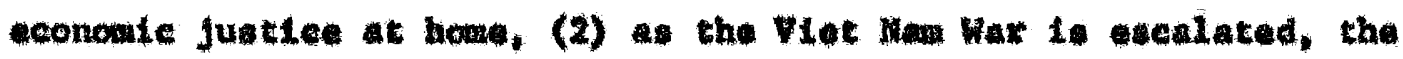

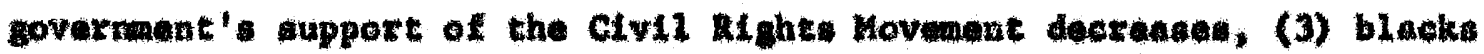

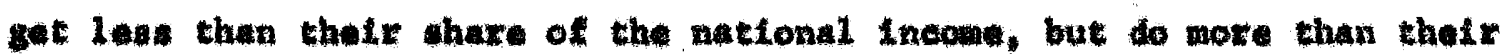

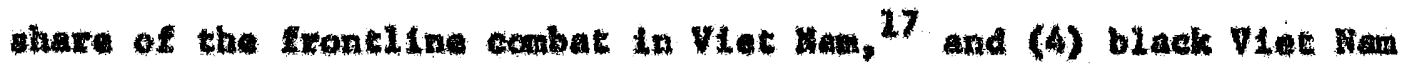
veteran, ftrat elaes soldters, raturn to Anerlea a becond alass aftiven. The Viet Men Mat, whether moral of tmoral, whethor lagal or 1120gal, ts trustrating phonomenon for wang Black Amoricans, Why

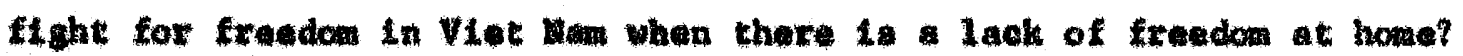
Why spend tax dollars la Vlot tow when they are needed at howe? Why

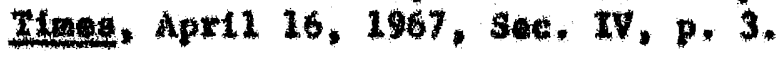


send black to fight tor self-datemination, when they do not themselves have this right The Black Fower Conference delegates tel the matcter wa so sartou they adopted remolution asktng black wan to anwwer the draft with the woxds, "Hell no, I won't go:"18 Anertea's military Involvenent in Viet ham and the struggle for pouer are contemporartes.

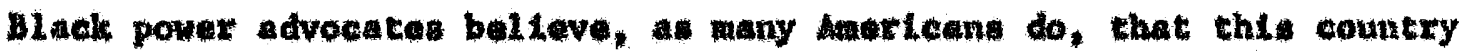
cannot have both "gune and butter." They wee Whice Anotica as villing

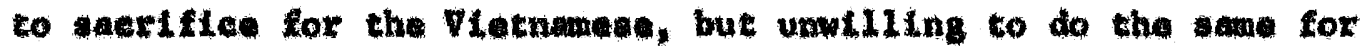

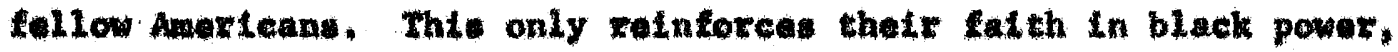
whteh doos not depend upon White Amertea.

Male tmanefpation In Ghapter 2 it wo noted that the black male has ban victiatued by his cul tute. He has boon conetancly frustrated In his attcapts to fulfill the accoptuble rolos in soclety. He has fwequently falled as father, hubband, and provider. He has bean unablo to demonatrate hi, wasculinity in the unual vay, wo be has attempted to prove his maculinity in othor ways. He hav done thin by leaving the Christian Chureh, moving to the north with of without hi wewn,

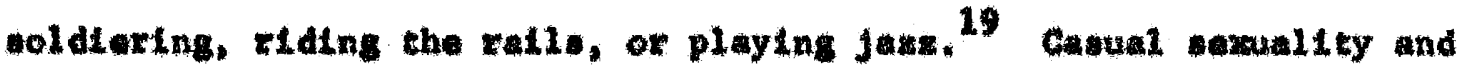
violence have alwo been the proofe of mantuod for blacks who could not futnith the custowary widence, 20 low black men axe proving thatx meseulinity by manefpating thenelves from the whites. They are not

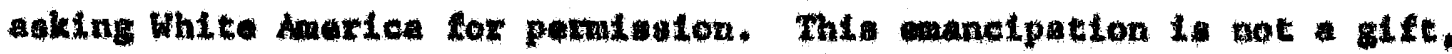

\footnotetext{
18 "Black Power Confarance," p. 314. 19-2andon, PP, 272-273.

20."Thinking Black," Levertels, Lxx (Hovmber 20, 1967), 39.
} 


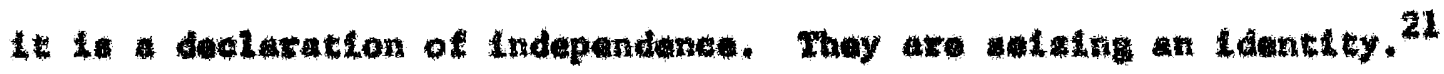

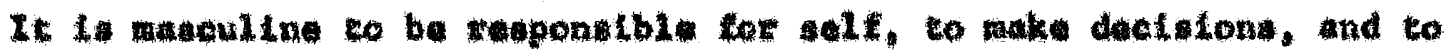

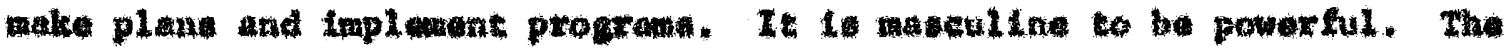

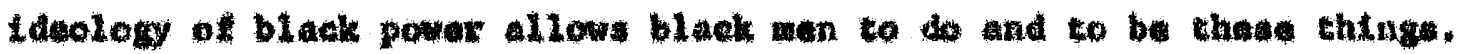

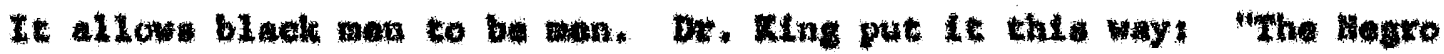
is no lowger baggtas angboly, He' no longer th that postefon of

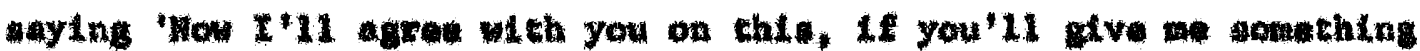

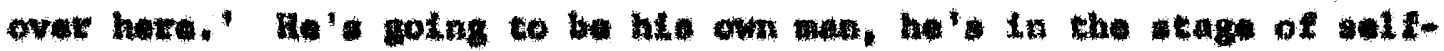

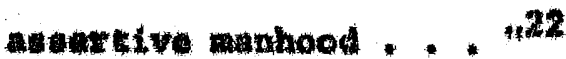

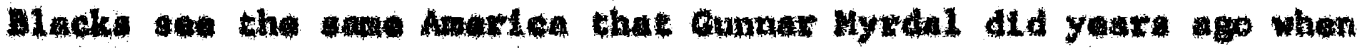

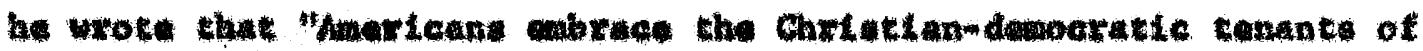

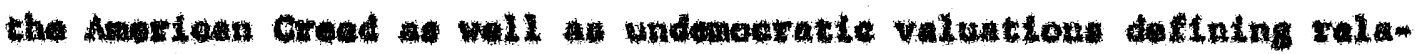

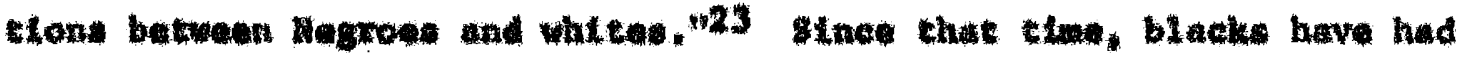

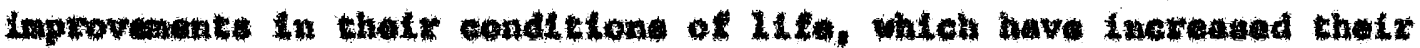
axpuetactone more raptaly than thone ane oxpectatioti have boen

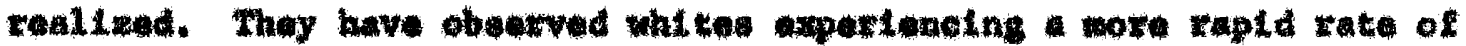

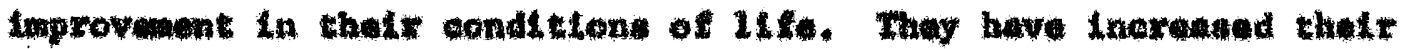

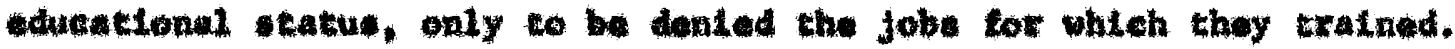

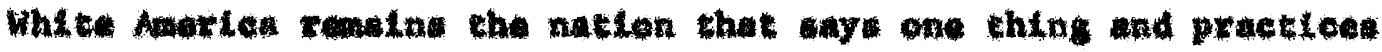

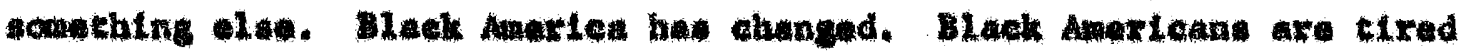
af wewering tho quatton, "What do you vant?" They axe trod of

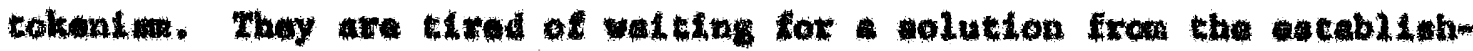
mont. Black power if thetr aldution.

\section{8azalon, 274 .}

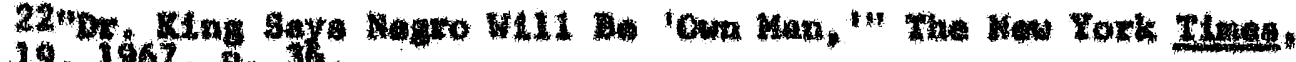
June 19, $1967, p, 36$.

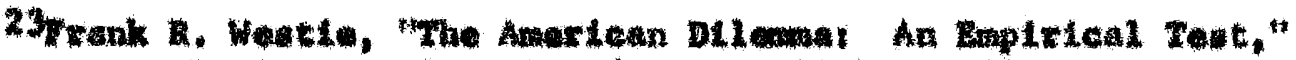

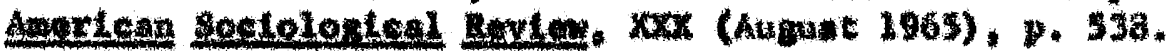


The Group or Individulisu?

Black people have generally accepted the tradtional Amertcan

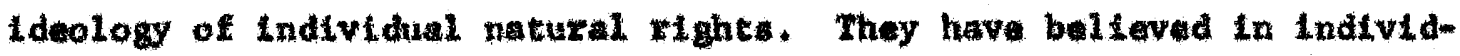
uallan, oven though they ware not allowed to be Individuals. They have belleved in worklng hard as individual to be auceosetul, only to have the by-produets of that eucesps dented. Thay have looked to the

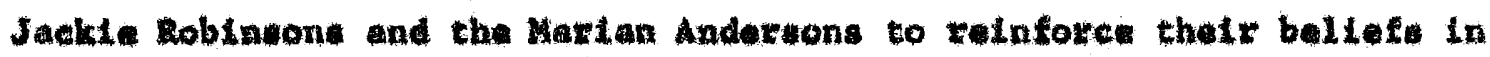
Lockean Amertea. But tow have "made Lt" individuals.

Ono of the wost widely proclalmed vittues of the Amexican polftical

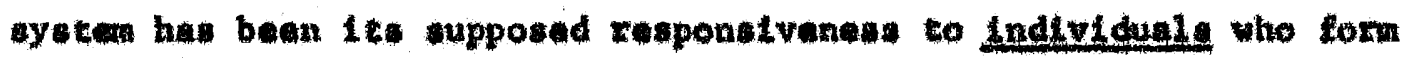

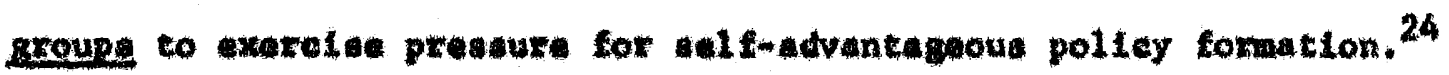
Groups, unltke Individuala, have the pewer to proclpitate a erleis In lnatcuttone, evon through non-violent action, 25

According to Camichael, bineks, as group, need to preciptate a exists in the Institution of rectes. He sald that whllo ladividual acte of racter axe widely daplored, White Amortea say thare is no such

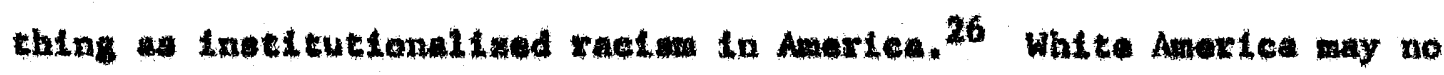

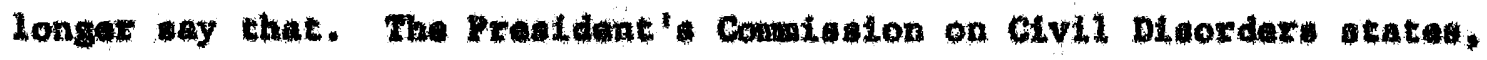
What Whit Amertane have never underatood . * to that wht to aoctaty

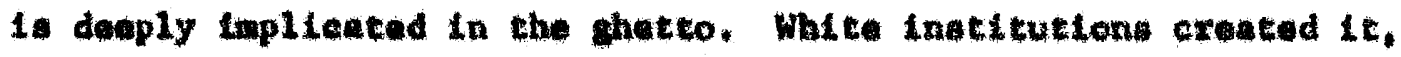

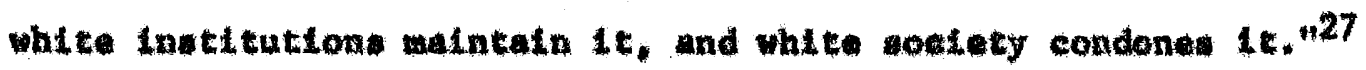

24 gethard Pishex, "teany Revioum-Negro Life and Soctal Proceas," Soclel Exoblesag, XIII (Wtater, 1966), 350 .

25itwoon, p. 507 .

${ }^{26}$ Carwlehael, "Blaelc Power," phonotape.

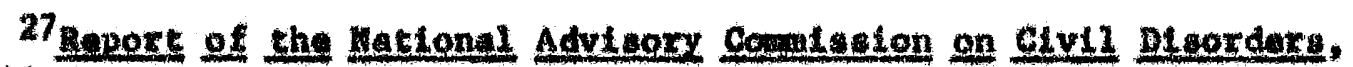
p. vil. 
Whit rack is a fack, not fantuy. Individual blacks have raraly been able to deal wht $4 \mathrm{t}$; but where lrdividula have falled, black power auvocated feul the group will succeed.

One reason the advocates ted the group wil succed where the

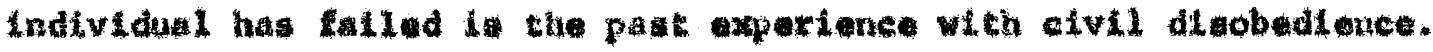

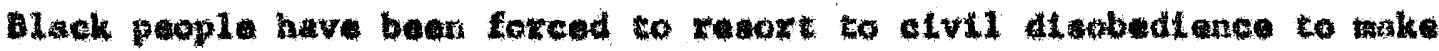
- potnt in Amorica. Pawe effore have whowi that when the Ladividual

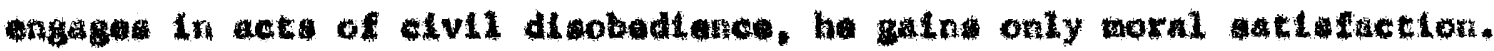
But whon group engages in elvil disobedience, there are apectito

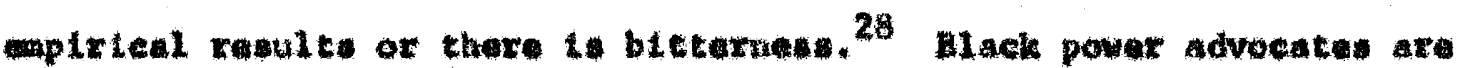

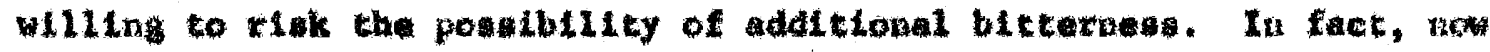
they any they are through carlag what the white comennity think about there. 29

So wo mut ak, "What to the nature of the power which la ought

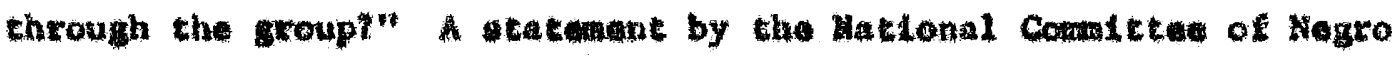
Chuxchen axwere the question thit way:

Power today is orentialy organizational power. It ta not - ching lyting about in the treet to be fought over. It

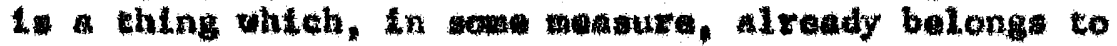

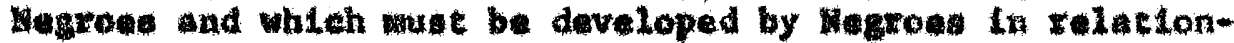
ahtp with the grent resources of this nation.

We mut not apologize for the axtstence of thi. form of growy pouer for have bon optroned as broup, not as individuals, We wil not flad our way out of the oppres-

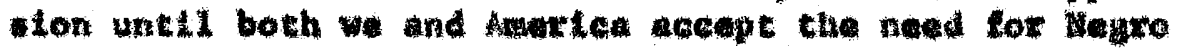

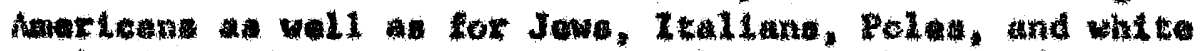

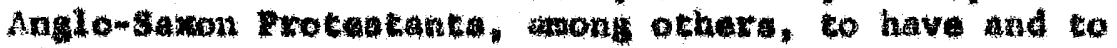
willa group pover. . .

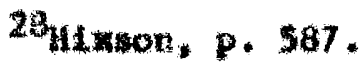

29 Carmtehael, "Black Bower," phonotape. 
We mut organtze. . In order that we can. . gatit power auffictent to change this nation's gense of whe la now tmportant and what we done now. 30

The route to polftical and sochal integration in America for other groups has been through the power generated by thetr own ingtitutiong.31 Black power advocates want to follow the extaples of both ethnic and spectal interant groups to "change thi nation" ange of what is not Important and what nuac be done now." Whethex or not they want Integra* tion will be discusaed in the next wetion.

Ethaic group have been held cogether from thin by cholce. The centripatal foree of natlonal culture, Ineluding language, heroes, and folklore, have formed the foundation for unity. ${ }^{32}$ Black Amarica is a group that has not hed contripetal forces acting to cotablish and malnm taln unity. The degree of untcy in slack Americe has been the reault of whit raclan. The roup ha bean forced togather from without, not held together fron within. Black power advocates intend to capltulize on this steution. 33 They hope, through the cultural goals noted in

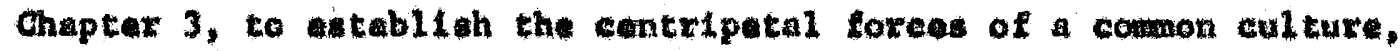
which wi11 unify from whtn. Blacks axe forced to be togecher phyaleally, black power wants blacks to be together spixitually.

Intereat groups In Anerica are interested in bringing about domeatic changes which improve their own positlon. Labor untons,

30"wlack Power Statemant by Matlonal Combttee of Negro Churehen," p. ES.

${ }^{31}$ Carmichael, "Toward Black Liberation," p. 642.

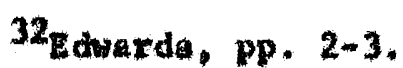

33 Lincoln, p. 538 . 


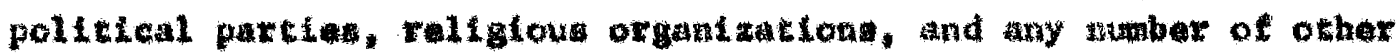
Lncerase group have organised for the banafte of the pople involved. Blawks, althoigh looked upow an ackine group, really have the potential of an latereat group. Many othule groups ax organiad only to keep the "old ways" allve. ${ }^{4}$ Interest growpe are organtaed to

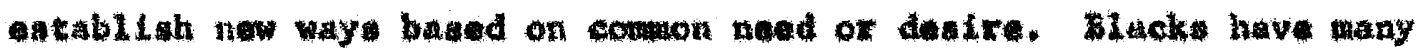

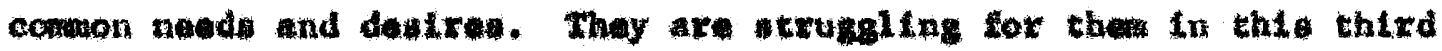
phate of the Ctv11 kight Hovenent. Mlack power is plat forw, a Coundation, for an active interast group.

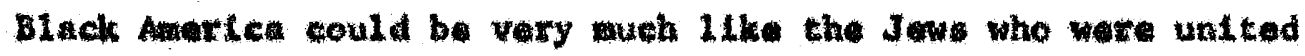
echnieally and by comon interest. It thay nove into a otatus of equallty ather groupa, web az the Jews have done, thay mus ba WIILg to accept all the riake of the confrontatlo of power,

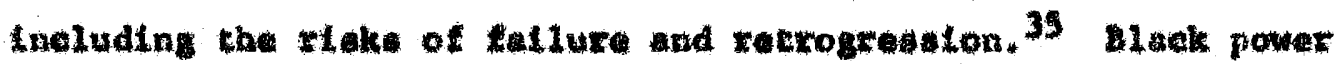

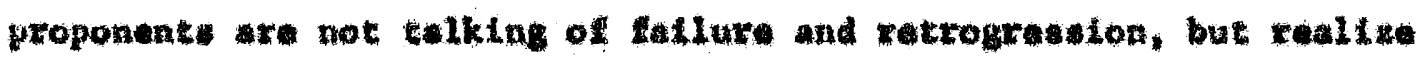

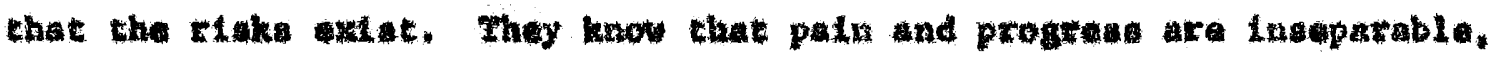
but thay are talking only of "goteling tha job done"

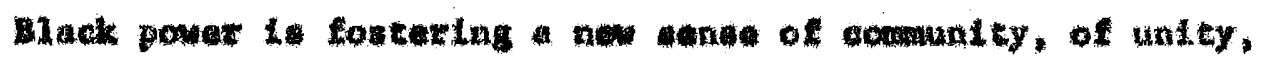

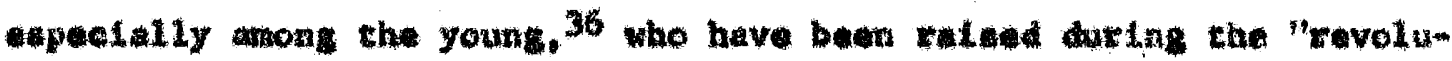

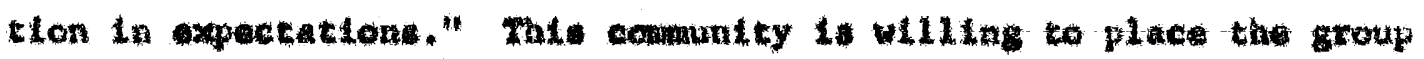
Eltat and worry about lndividuli in latur *

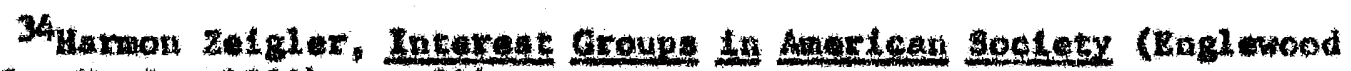

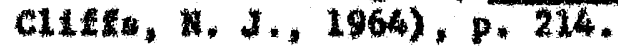

${ }^{35}$ clark, p. nv111.

36tiven, 21 . 


\section{Integration or Separatim?}

According to Thomas . Pettigrew, Black Americans, Individually or as a group, have three cholces. They may move towards, agalnst, or away from their oppressor, White America, Traditionally Black Americans have moved towads theix oppressor by seeking acceptance into ractilly Integrated soclety and imltating white ways. 37 They have accepted and emulated White Amexica and looked towards eventual Integration as "the means and the end."

The second chotee, moving against, and the third chotce, moving away, are assocleted with Black Hationalism. Blacks who move against whites pasatonstely hate then (e.g., the Black Mus1tma) ${ }^{38}$ and blacks who wove away from whtes destre to escape (Marcus Garvey" Back to Africa followers). 39 Black hationalists are men wo desire to leave White Ameriea and inhabit an envigloned black utopia where black men control themelves. They reject the white present for black future.

The question 1s: Which is the choice of black power? The answer 18: All three. Black power has within 1tself elements of all three cholces. The cholces and the black power posttion are discussed below.

Black powex 18 a form of black natLonallom. Karl W. Deutgch, political geographer, has defined natlonalisn in three seps. 1 . Ethnie complomentarity, what anthropologist call culture, makes a people. There w11 be an integrated pattern of configuration of commun-

\footnotetext{
${ }^{37}$ Rettigrew, P. 27 .

38 Ib1d., pp. $34-36$.

${ }^{39}$ Ibid. , p. 47 .
} 
lcating, rembering, and acting. 2. A natlonallty i a people pressing to nequire menure of aftective control over the behavior of 1t neabers. 3. Nationallties turn into nationg (not tates) when they aequire power to back up thet aspirations. 40 Undig these threa stepe as criteria one notes that black powex 1 attempting to establigh an thnie compleatentarlty anong black poople and that blatk people, once unitad, would work together for ouffletent power to back up thelr applratlons. Thus, black power is a form of nationaliam.

Black power is concerned with galning power to use here in Amertes. This separatea them from other nationallet group that have been concerned with oparation through agression or escaps. They lookad towards utopt through the gyes of 1dealiets. The President' commisston on Clvil Disorder" stateg that black power edvocates are doing the same thing. The Conataston balleves that black powex followers have retreated into an unreal world so that they can avold the confrontation of Integration. 41 I. black power merely a detente mechauism, which allowg bleck peopl to retrest from realley? Ho, black pown is a reallatie anower to pluraliatic soctety. Black people want powar to use in dolng what they can to help themselve right here in Amartea. If this mean the abandonent of the old Ldaal of integration and the acceptance of geparetlan, ao be $\mathrm{lt}$.

The black power position on lntegration can best be stated by

40. Kar1 W. Deutach, "The National Comunity, Ite Formation and Relation to the State," in Pollties and Geographle Relactonthles, ad. W. A. Dougla Jackmon (Inglanood OLffs, N.J., 1964), PP. 115-118.

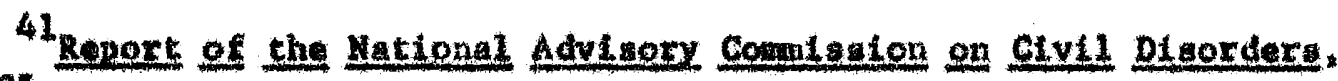
p. 235 . 
quoting an advocate, Dx. Wathan kare.

"Integration started as means to an ond. Then becme an end in itaelf until black Power pugh begar. "142

"So we hove realized that integration and cquilitation are not synonymoua. Moreovar, equalt ty if not aynonymous with camoneas. "143

(Reporter! Does this mean you are abandoniag integration?) "Yea, as an end tn ttaell. . I can lmagtne a utoplan vorld in which everybody would be integrated. But thip does not seem to be posuble under the present thinking and structure. 444

Token Incegration i no longer accoptable an alternative to equallty. This token Integration is seen by black powex advocates as a drainer of black talent wheh in meeded to make black power work. 45 Thue, they are encouraging tutegrated blacks to return to the ghetto and to thetr share in the struggle for Pover.

Some proponent: of black power seoparation tha flrat atep towarde complete Integration. They belleve that integration w11 follow aeparatism, becaute white and biack vill mot each other as equals.

The thetoric of black power dow include acta references to Beparate countrles, to black stated and whice ctates, and to the valu of complace separation. A falt evaluation excludes this as oven a retote postbLlity. Black power people, who generally are realiats, know this also. This oratory tor pollctcal separtition cone from the extreme element in the black powar following, wheh w111 be discusaed in

42"Black Foner-Its Coals and Methods," p. 65.

$43_{\text {ibld., p. } 64 .}$

${ }^{44}$ Ibld , . 65.

4 Carmichal, "Black Power," phonotape. 
detall when the quatton "Violence or non-violence?" is angwered.

Black powex $1 \mathrm{~s}$ Angrican. It it unfortunate that black power has becone associated in the press only wh the idea of black wationelusa and aeparation to the exelusion of being asaciated with Anericanism. Black power 1 sot rejecting whtk Amerlea or America. Black power advocates are American. They have no place al to so, nor do they want to leave. They at realistieally looking at un unpleasant, un-Aater icar phenonenon and atteapting to do something about 1t. Hont of what they vant, wout of what they do, and most of what they propoes can be described as Amertcan. They are trying, In thelt own wa, to make Amertcan ideri realithes. And in thia way, they are moving towarda White Amertea, not ausy from it.

\section{Vtolence or Nan-violence?}

It L an Ameriean tradition to tak "caute" Into the otreets. Wcanen won the right to vete and unione won wertows recognteion demanstrating publicly. Hlack people have done the same thing sfrce the Suprene Court Deciston of 1994. They have uned the non-violent: mass demonetration as technique of selt-exprasston and polltical action, but often they have been able to promote only the "revolution 1 f $^{\prime}$ expectatione" and not concrete resulte.

The black mat, who once vas wiling to andure the rigors of uonviolent action, 1, for the nost pare, fad up. He is fad up whth the pollce dogs, the bombing of his churches, and fat housewives screamiag "nigger go home." He"s trad of whte college boy sptecing on him as he watches white polleenen drag teen-age girla off to jall. The combtrant 
to Chriutian forgiveness, Chrigtian buml1ty, and "wurn the other cheek" lo thinning out. Non-violence, plue gelf-nefenge, to the now commitment of most black power advocates and most black people. $40 \tilde{~}$

Young black people of the early $60^{\prime}$ 's balleved in non-violence. swcC staffer have been descrtbed as having a "healthy disreapect for respecabilicy." They were not ashamed of being agtetors and trouble akers; they it the canerce of democracy, but they practlced nonviolence. 47 The Civil ight Moveneat today to not confined to the couth, nor partleipated in only by black southern Chriatians, black college student, and whte 1 iberals. The movenent coday is centered In the ghetse. Young poopl of the late 60' have not sean afficient results from non-violent mass denonutrations, Because they are ghetto young people, they have had axpertence with violenea, and they see it a postble solution. ${ }^{48}$ Generally they arc the onea who are leading the violent aspeet of the Civil Rights Hovewant, but they are baing supported somewhet by Civil Rights Organizations, which pattern their progras to appense the arowing milltancy. 49

Primarlly the vlolence in the eftles wat be viowed as the respone of the black poor to thetr soclal and wconomite conditlons. 50 To many, eppeclally whtea, howevar, violence is conaldared to be planned and aubveratve. The wordis "black power" are urmistakenly linked with

$46_{\text {Bazelon, . } 283 .}$

47howard Zinn, skce The New Abolitioniets (Boston, 1964), p. 8. 48 Proctor, P. 25.

49 Jaclonan, 15 .

50 plven, 20 . 
viol eneo and aubvareivenas, even though only a few advocates sea violence a means to an and. This linkage is due to television coverage and the verbal hostilltien of stokely Carmichael and H. Rap Brown. The television coverage of rloting often depicts a "black power leadex" and his host.11ty. Carmichal and Brown denoune Anerica a forelgn power and reply to President Johneon's warnings aguinet violence with counter warnings of violence and danage. 51

The WII reported that the growth of the concept of black power it 1967 "ctanted a ellmate of unrest and (black powar) has come to man to many Megroes the 'powex' to Flot, burn, loot, and k111," Stokely Carmtchsel, H, Rap Brown, and other mL1tants "goved the seede of diocord and hope to reap in 1968 a yoar fllled with axploalve racial unrest."52 There 10 no doubt thet Garmlehal, Brown, and other black power militant do call for violent action which counds aubveraive. Black Amarica, according to Harris Survay, does not agrae with the allitant on the value of violence. After the wlots in the aumaer of 1967, 75 par cent of Amerten" blacks felt only a mortty of blacks supported the rlots. When asked if the rlote have hurt the black cause, 60 par cont of Black Anarlea answared yes. Oaly 12 per cent of the blacks tnterviowed wald the rlote have helped that caube. 33 Backs not only seal the rots have hurt thely cause, they know 910

51"ghades of Black Rower," Economiat, CCxK (Septumber 3, 1966).

\$2"Tri Report," Faets gx E11e, XXVIII (January 11-17, 1968), 13 . 53" After the Rlote: A survey," Newaved, Lxx (Auguet 21, 1967), 19. 
they hurt them physically and matertally. The people killed are black. The ones who lowe their homea and thekr belongings are black. Except for those concalcally involved in the ghetto, whted are raraly hurt by the rioting. They sit, look on, and blame "outside agteation." 54 They do not underatand or belleve as black people do that the violence in spontaneous. Blacks liat the causes of rlocing the lack of progrees in galning equality, the lack of decent housing, the lack of jobs for young people, and the lack of good educationed opportuntetes, 55 Whetter they are spontaneoul or planned, born of frustration or subvarsivenes, ractal rlote in this countey are real. And the rloting ia stffening wht realstance. Dotrolt" Bepresentative to Congress,

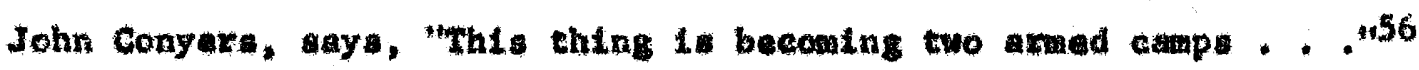
The c1tizens of Mewark, Now Jersey, know what he 1. taiking about. Whil. Anthony Imperlale and hi Horth Ward CLtizen Councti are coungelIng whtce to arm thesgelven, Willie Wright and hio Wegro United AfroAwertean Aasoctacion are counguling black to do the thing. 57

Hav the riot season becone an acceptable part of Anerican life? W111 we continue to have hot aumeret Probably, yes.58 Frustration w11 continue to be the black burden in the lramdiate future. Leaders,

${ }^{54}$ Ibid., p. 18.

59 Ibid., p. 19.

56. "What Nust Be Done," p. 35.

57victor L. Stmpon, White Vigliantes, Nagro Militants Escalate Arms Race In Growing Unxent in Now Jersey, "The Oregonian, Warch 17. 1969, p. 21.

58:"What Wust Be Done," p. 34 . 
black and/ox white, must resolve that frugtration or we w11 continue to have vlolence and $1 \mathrm{t}$ will be on increasing acale. 59 until or unless White Amertens or Anertes 1 tself, to vietimized by the violence, Whites are undikely to do anything to halp prevent $1 \mathrm{t}$. They wLI only tep in wth power to enforce "1aw and oxder."

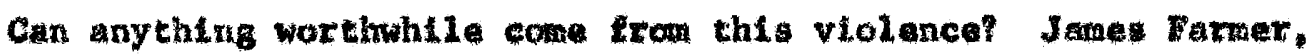
Lomex Hattonal Director of cont, teels that black angex will be creative. 60 Thi anger by be a very valuble centripetal force for untly. This anger way bring about the govarnment action whlch the President's Comiaston has ouggented. This anger may bring about action from private entorprise.

Violence of the threat of violence has been very real force in al1 black coumithes Watto. White Amerlesne are shocked. Thay thought black poopl ware doclle and weak. Now they mut vien black people th a different waner. Thoy wat reallze that blacks are through belng relegated to second cliso cltzenuhip. They are through 1 istening to White duertca' promises which are not fulfilled. the entire nation 1. caught in an 1ntersection of two Imagen where 1 alway thought there was only one. 3o what sarted as an dentity criata for blaeks is turnIng tnto an identity crith for the nation. White pople are percelving a sow Black Amertca, ready to defend 1 tsel $f$, but generally not seekligg violence. Aftar White American read the President"s Matonal Advisory Commlabian's report on clvil di arders, they may vell percelve of then-

\footnotetext{
s9ordon, 58 .

60uele11an, p. 37 .
} 
selves differenty also, If they do, naybe they w111 qute asking, "What do they want? ${ }^{\text {st }}$ and start considering how they can support black people In their fight to make fredom ras and substantial.

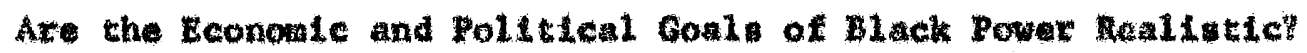

Black peopl are Locmed wintn the Unted states in weh a way that hey way very wall be able to realise the gol of black power. especially the polltical oned. Ironteally, thi coneentration of blacke,

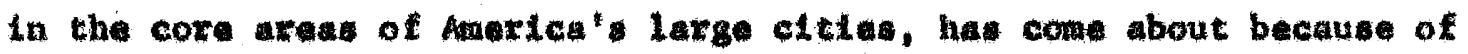
segregation and migration caused by conowle necesst.ty.

Black American have become an urban people within the last three decades. It was not until after the depression of the early $1930^{\prime}$ s that the gouth began to Induetrialiee. This Industerlalization and the accompanylng farm mechantzaclon wade black farm labor almogt obsoleze. Blacks roved in great numbers to the clties in a was oxodus to the north and the bordar tatea. In 1930, 78.7 per cent of Aurice' blach peopl. lived in the leven confedurate atates, By 1960 only 32.3 per cent Iived in the south. 51 often instead of the jobs, the nice homes, and the "better way of 11 fe" they looked for in the elties, they found unexployment and axtstence in the ghetto.

Even when black found jobs, segregution lsolated then from the total coranumb. The 1960 consus ahows that in wost large alties 90 pex cent or more of the black lived togethar in black section of town. Colow was the only comon characteriatic among the eltizeno of the black

$$
\text { 6L Ladd, p. } 22 \text {. }
$$


nel ghborhood. 62

Blacks, whether abl or unable to provide for themelves, bacane the vietims of rectal rastdential segragation. nuctal gegregation in Amertce is greater than class gegregation and blackmhite segregation 1. greater than that between any other natlonality group and native whites. Thts high degres of aegregation is true for chtins in all regions of the country and for all types of chties-marge and and1, Induatrial and comarelal, notropoliten and aburban. It Li true whethex there are $100,000^{\prime}$ of blektes or only $1,000^{\prime} s^{63}$

Thua, segregation and migration have pleced black in an advantageous posttion to develop and axerctae political power. Blacks are now

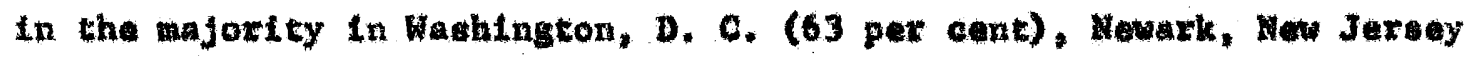
(51 per cent), and Gary, Indiana (5s per cene), Within fifteen yearu they will constitute majortty in Baltimore, Ohlcago, Cleveland, Detrott, Phlladelphia, st. Loula, Oakland, and rrenton. 64 Unles whites are able to substicute matropolttan bureaucracles for city goverments before blacka come to powar, black people should coon be abla to control many of Amarlea" large eitiae.

Bven when not in the wajority of in control, black people are exerclalng thelr polttical power. They are becontng a vital considerathon In presidential and atatewide electiont. On the local level, they

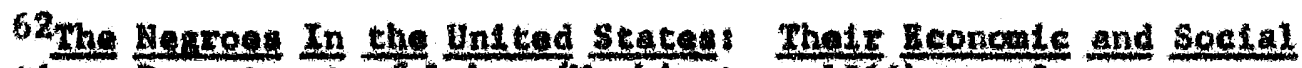
s1 tuation. Department of Libor (vanington, 1966), p, 3 .

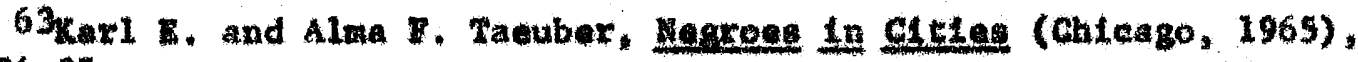
pp. $34-35$.

64, "What Wust Be Dona?" p. 34 . 
are merging as major force in the liberaltatelor of congressional distrlets and weropolitan axeas. 55 The black vote won Tunnessed, V1rglaia, Florida, North Carolina, and Arkansas for Prestdent Johnson in 1964, 66 In 1966, southern black votes the difference in lacting one v. S. Senator, one and probably two govarnor, and two v. \$. Representatives. They also placed swenty blacks in three Bouthora loglelaturea. $\$ 7$ Notthern black voted captured two ckty adninferation by electing Carl B. Stokes and Richard Hatcher, mayor of Cleveland, Ohto, and Gary, Indiuna, respectively.

The black vote, eapectally if 1t ti used collectively, to very - ignificant. Data on black voking in presidentil loctons ance 1952 polnt to an Ineraase in voter turnout, espectally when compared to the strble turnout of the nation whole. 68 Another weraure of the atgnifleane is the estimate that the Democratic Party would probably

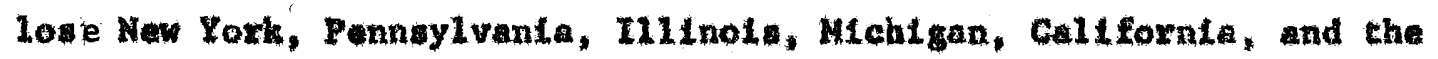
outhern stated thot were for Johnoon in 1964 wlthout the black vote. 69

Greater influence in national politice dopends upon atrong local organtation capable of promoting alectoral participation and asuring

${ }^{65}$ Dewey $W$, Grenthat, Ir., "The South and The Reconstruction of American Rolltice," Journal of American Hetory, LIII (September, 1966), 237.

66 tarmer, p, 186.

67 c1eghorn, 24.

68 Anthony M. Oruz, "A Reappratsal of the Soctal and Polttical participation of Negroes." Ameriear Journel of Soclology. tuxx (July, 1966), 44 .

69 gagar, p. 175. 
discipline. 70 the mathonal political partien are esmentidiy state and local perty organizatiout which cone togethex evary four years to norinate candidates for the presidency and vice-presidency. The party organtzetion in the flfty tates are cohestve only in the barest sense. The economie, soctal, and political conditions that fonter locallat and the priary taportance of locel colutions Lnour that the balance of political power at the nackonal level is wh the state party organtak tone. Candidates and party unt to which emphatze national policy at the expense of local intereste are apt to lowe local party aupport and eupeclally black support. 71

Irom a local politicul base of power, which teontrols the black comuntey and andmen the total emonity, black people will be able to influence, more than they now do, the veladtion of goverrmant office holdars and the adoption of state and wational policy. With wost Amerleans, It 18 not very important wht the goverronent dectdes for them and how, but, for Black Amerleans, it my be very tmoportant. 72

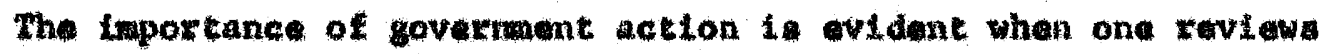
the conoulc goal of black power, A guarantedarmul ineome and the obtalnance of foderal money are the prorogative of the Lederal govarnment. Four of the other goals, abiliebmant of black finarial Institcutions, eatablibment of black housing and bullding cooperstives, rull employment, and job training, could wo be realized through

$$
\begin{aligned}
& 70_{\text {plven, p. }} 23 . \\
& 71_{\text {Rogow, p. }} 19 . \\
& 72_{\text {Goxdon, p. }} 68 .
\end{aligned}
$$


governuent help.

W1thout govarment support the ecomolc goal are unobtalnable. Blackm are poor people. Their poverty is one of anfored dependency. This dependency arouses the anger of the affuent, ${ }^{73}$ who then baccise inereasingly reluctant to we government power to fight poverty. Tradtionally the poox of Anertea have been an unergantzed, powerless people. slack poor people, a we heven, do not ned to be. The black poor can becono politically strong. Ixporience ha show that poverty gtves the poor very 1ittle control over thelx oun behavior, but once they are engaged in sucesentul soclal action, they gain power, even if thetr incomes remain the same. ${ }^{74}$ Blacks are In postion to engage in wuch sockal action and galns made WLII bacowe accelerated by virture of the power realized at anch point of oucenss. 75

The basc polfcteal goal of black power, control or rightiul ghare of control, gems to be reallatle one. Black poople live together phyleally and there is evidence that the cultural goal of unity is rot as untalistic it wa oven five years ago when black stopped talking about integration and started talking about closing ranka to struggle for Powar. They hould be able to engage in succesalul social action and auccessful politteal action in such way to assure control over thetr own communttes. Power w11 bring control and control will bring additlonal power. This power may then be used to work for the realiza-

73taxren C. Haggatron, "The Power of the Poor," in Boverty in America, ads, Louls A, Tarman and others (Ami Arbor, 1965), p. 326.

${ }^{74}$ Ibda., p. 329 .

75 Ther, 350 . 
thon of black powar's econonic goals. It may well be that the Inpact of the CIvil Righta Hovenent, the struggle for Power, is the strorgeat and mot positive support for the ffort to eliminate poverty and disadvantage from the "American Way of Life." 76

What Are the Organizational Needat

Many blacks have seen the ambigulty of the word" "black power" as their major atrength in rallying blacks.77 twaryone knows they have somathing to do whe uniting the race, mink poople feel proud they are blatk, practleing self-defenwe, and obtalning political and econowic power which ean be used to obtakn jobs, houstng, and better educational opportunttles. Black power is something that sounds urelting to moet blacks, somethling thay can support.

When "black powex" becme Iniced do closely with violence, complete ueparation, and ubversivenew, many, Lncluding DF, King and Roy WLIkIne, denounced the words, but conthued to mbrece wost of the ldeal .78 Because of this 1Lnkage, the time for ambigutty is past.

"Black powar" neede to be clarified. Th neads to be deflned. And, then, It neads to be symatemactenliy lmplenented. Fonter havywaight boxirg champion, Gassius clay, has nevar been notad fox intellectual atatements, but he does sem to know what he is talking about when he says the bluala man w111 never bo free "as long as ho has a leader on

76 Whater, p. 155.

77 "The Many Meanings of Black Pover," Now York 1mes, Ju1y 23, 1967. Sec, TV, P. 1 .

78 "Race in in Revarea," ". 261. 
every street corner. $\$ 79$

The struggle for fower is not partelpeted la by just the middle class adult as was the legal irge phase led by the WMac, of by just the enddie clas college tudent, the whit 11beral, and the poor southerner an was the non-violent, direct action phase led by sch, cone, and sNCC. The struggle for Powat $1 \mathrm{~s}$ for and by the gasses. The massas need drection, Leaderwhip, and organdatton.

It black power is going to be anything wore than "glogan of the $60^{\prime} \mathrm{s}$ " black people wust define $1 \mathrm{t}$, wo that they are in grement about direction. Then they must organtze. This organtzation may be baud Wthin one of the oxiating ctvil rights groups of thin sone new group yet to be fomed, Flgure 1 indientes the militancy and appeal of the organtzations now ctive, Thl information w11 help in evaluating which of these groups has the beat potenthal for leading the masses.

79 "clay Urges Parley of Hegro heders," The New York Imes, July 1. 1967 , p. 10 . 
Fgura 1

M11tancy and Appeal of Pxotest Organization by Ragion 80

\begin{tabular}{|c|c|c|c|}
\hline $\begin{array}{l}\text { Degree of } \\
\text { Hil Ltangy }\end{array}$ & $\begin{array}{l}\text { Noxth } \\
\text { Won }\end{array}$ & South & Appea1 \\
\hline \multirow[t]{4}{*}{ w11tant } & $\begin{array}{l}\text { Block } \\
\text { Husl Lma }\end{array}$ & suce & $\begin{array}{l}\text { Studenti: } \\
\text { wotking class, } \\
\text { and disposessmit }\end{array}$ \\
\hline & & sace & $\begin{array}{l}\text { Working claes } \\
\text { and etudents }\end{array}$ \\
\hline & conse & cone & students \\
\hline & NAACP & NAACP & $\begin{array}{l}\text { Studenta and } \\
\text { lddle claes } \\
\text { adults }\end{array}$ \\
\hline $\begin{array}{l}\text { least } \\
\text { militant }\end{array}$ & $\begin{array}{l}\text { Uxban } \\
\text { League }\end{array}$ & $\begin{array}{l}\text { Uxban } \\
\text { Lasgue }\end{array}$ & $\begin{array}{l}\text { Madle class } \\
\text { adults }\end{array}$ \\
\hline
\end{tabular}

When evaluating the possibility of these axtstigg organimations maklng the goals of black power national reallties, the Urban League and the MAACP probably mut be elluinated, Both eppenl primarily to middle class dulte instead of to the manas of poor blacks. They are the two lesst allitant, so black ghetto youth axe unlikely to joln them or even 11:ated to then.

SGle hav never appealed to the black wases in the north. Now that. it has loot tts chartsatide leadar, it is unlikely that the sche and itg request for 8 "B11 of Rights for the DLadvantagad," many of the economic goald of black power, will be able to Inttiate

$$
\begin{aligned}
& 80_{\text {Jaclaman, p. }} 13 . \\
& 81_{\text {Meclellan, p. }} 19 .
\end{aligned}
$$


wideapread arpport throughout the nation*

Many black people cannot accept the extre milltancy of swcc and the Black Muglina. Becsuse of thle, they heve vexy 1ittle chance of bringtng Black Anerica under a sugle banner.

The Congress of Racial Equality, which was founded in 1942 a a direct action efvil rights group, sewe to be the extsting organtzation behind which black people could unlte to achleve the goal of black powex. Jame Farmer oay it it a mueh different oxganization today then the "romantlc 11ttle organization" which in 1961 freedom-rode through the south and cratned new cadres in the techntques of non-vLolence. 82 CORE genas to be able to change with the cimes.

Figure 1 indicates that cone appeals pximarily to tudents. CoRt offleialy, however, Indicate that mewber uhtp is increasing and the Alnanclal statu lmproving the "Ifetle people" become involved with thair $\$ 1$ and $\$ 2$ donstione. 83 cone 1 is looklng for wide aupport among Black Amerteans, Ito convention lat year was an open one tor all black people and all black organizatione.84

The President's Cowaisaton deacribes Cont as more flexible than sNcc, because it approved totally independent political action outside the astablinad politieal parties, as skce does, and also approves working within the Dexocratic Rarty, stec doen not. CORE is further described an organiation wheh seako to form alliances with other

82 Barmer, PP, xvili-six.

83"cons El Lminate 'Mul ti-ractal' Tem," The New York Times, July $6,1967, p, 21$.

84 xbed. 
groups and advocates violence only in self-defense. In a further compartaon with sNCC, the Commismion atates, "Both groups favor cooperatives, but cone has seewed more inclined toward job-training programs and developing Aegro entrepreneurtal class, based upon the market within the black ghettos.

Cone, which in 1961 was wo-thinds whtte, ho now correcthy cenLlared by blacke and whites as a black power organiatclon. CoRE"s leadershtp is black; cone" prograen is for black people. If any oxiating group is to provlde the orgunization neaded for unity and the realization of the economic and political golls of bluek power, it will probably bo conts.

The thing cone lacks nost is dynante leader. This leader nuat be unlike past eivil rights leaders, who vere often devoted to doing job for the people: A leader it needed who will be able to motivate the people to do a job for themelves. 06 This leader al a neede to be able to convince the black middle clase to "xetura" to the ghetto and help the1r brothare. Floyd Mckiaglak, National DLtector of cons, gays, does, and wites all of the right things, but he has not bean able to genarate the enthuafastie following that others, such as Dr. King, have.

There If no roos In a black powet organization for whites. In July, 1967, cone renoved the vord "nult-t-ractal" from the description

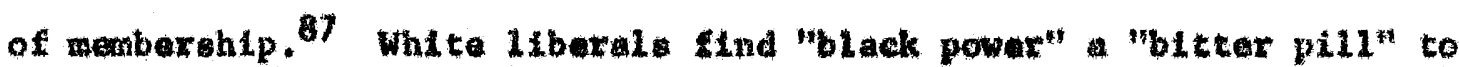
gwallow. They apoke for blacks when they ware unable to apak for

85neport of the Mattonal AdvLaory Commiasion, pp, 233-34. 66Losiax, p. 133 . 07"cont. Elininates "Multi-racial" Term," p. 1 , 
themselves, They have contributed time, monoy, leadership, and Ilves to the black cause. 88 Now they are told to let black work for themaclves, They are told to go into thelr own conumities and teach nom-violence and ulpe out racisa. 99

It is clear that an alliance with white liberals is out, but posalble alliances with other groups are not clesx cur. Black organtrations often diucus the pros and cons of foming alliances. If and when coke, or some other black power group is able to moblitize Black Americe for action, the group w11 need not debate the pros and eons of seaking allies. It will be sought out by others and offered genuine concenslons, because it ha strength to bring to any alliance. 90 Befor leaving the decusaion of organtation, one additional point should be wade. Black America has an untapped resource-mit numerous voluntary assoclations. Blacks are wuch more likely to balong to polltleal and church groupa than thetr white counterparts and equally IIkely to belong to elvic groups. If we considex only the low econonic class, to which most black belong, we ggaln find that blacka are more likely to belong to voluntary associatione than whites.91 the result is that in black communtede there are exlating local voluntary associations, ranging from bridge clubs to political dicusaton grouph, through which a national organtzation, such as core, could work.

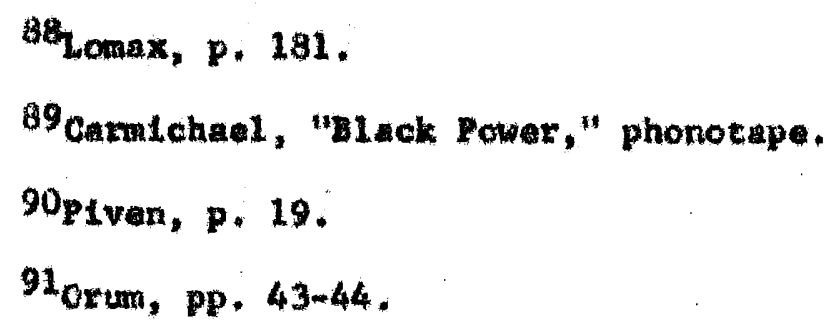


If black power is to becone reality, through the accomplishment of Its political, cul tural, and economic goals, then there must be directkon, leadership, and organfation. Hirat black power mast be fully defined. Then an organdzation must develop which will be able to motivate the mases for action. Then the masses must aet in thatr own behalf. The Congress of Racial Equal1ty, if te can find or develop the necessary leadershtp, way be the instrument through which black pover beccues a reallty. 
CHATTER 5

BLAGK POWRR AND THE FUTURE

The vorde "black powex" mey dLe. They way even be disearded by Black Americe because of the connotations of violence and subveratveness. But oven if the word sre baent, this writer believee, the mood and the progran w11 continue, The mood and the progran of black power are, In the opinion of this weiter, vexy construetive phenowena for two major roasonst 1. Black power promotes pychological healthinesa, and 2. Group action will bring conerete Improvenente to Black America's way of 11te.

Eychologieal healthiness. The improvenmt in nelf-image and the raclal image is paychologleally heal thy. For year young people, who belleved thenselves inferlor, grew up to be infartor. Now we have a generation which doa not feal the totality of inferiority that past generatione did. Today"s adul te heve 1 lved through the "revolution in axpectatione." They know what hope it. They have seen aone progres", which polnte to thet own worthiness. Today ' youth was born into hope, not total despalt. Black pople are beginning to dovelop favorable 4elf and racial concepts. Black power ideology gives them the opportunfty to continue to grow in the knowledge that "they are good" and that "black is good,"

Group action w4l1 belng a bettax way of 11fa. Black Ameriea has sean other groups, both ethnle and interest, consolidate their Individual member' strength into group power. Black Anerlca hopes to 
do the same, in oxder that they may uae thelr group power to raise the

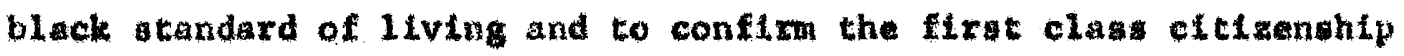
which is inherently theirs. It seems entroly posstble, ard even probable, that they w11 be auccesaful.

The Idealogy of black power to peychologically and natertaliy constructive, not descructive. It would be alatake, however, not to consider the posstbility that the practice of black power will be destructive. The following questions realn to be answered.

1. Does black power serve a catalyst for additonal ractum In Anerlae?

2. Will raclal rloting lead to raclal war?

3. Wh11 black power afvide Amerfents into two nationg, whose ethute complenentartites are so different that they will cense to commulcate with woh othert

4. W111 black power realt not in group unity, but in further diviaton of black people Into the "Integrated," the "moderates," and the "mill thants"

5. To hat extent, 1 any, wil the past experiences of black people tend to wigate thelx proper ua of power?

6. What are the internat lomal implicationm?

W111 all Americans now be viewed as reclata-both blacks and whiteat

W11 the miltant apects of black power spread throughout the woxld?

To what extent, if any, is black power part of an international comanist plant 
One can only speculate about the futura. "Black power" may be judged by history as destructive, both peychologleally and materialiy. The personal oplnton of this wrtter 1s, however, that history w11 pass favorable judguent on the ldeology and practice of "black power." 
"After the Riots: A survey." Newsweek, LXX (August 21, 1967), 18-19.

Arnold, Martin. "Nowark Meeting of Black Power Attended by $400 . "$ The Now York Times, July 21, 1967, PP. 1 and 34.

Batchelder, Alan. "Poverty: The Special Case of the Negro." in Poverty in America., eds. Louls A. Ferman and others. Ann Arbor: The University of Michigan Press, 1965.

Bazelon, David T. Bower in Amertca: The Bollkice of the New Class. New Yorkt Nev American Library, 1967.

"Black Power at the Pol1s." Ebony, XXIII (January, 1968), 23-35.

"Black Power Conference." Eacte on Flle, XXVIr (Auguat 3-9, 1967), 313-314.

"Black Power"-Its Goals and Methods." U. S. News and World Report, LXII (May 22, 1967), 64-68.

"B1ack Power P1ay." Economiat, CCxx (July 2, 1966), 39.

"Black Power, Statement by National Comalttee of Negro Churchmen." The New York Tlmes, July 31, 1966, P. B5.

Broon, Leonard and Norval D. Glenn. Iransformation of the Negro American. Naw York: Haxper \& Row, 1965.

"Brown Arrested, Repeats Threats." Facts on File, XXVII (August 3-9, 1967), 315-316.

Carmichael, stokely. "Black Rower." Phonotape Number 600, Portland State College Library, Portland, Oregon.

" "Toward Black Liberation." Masaghusetta Review, VII (Autumn, 1966), 639-651.

"Carmichel's Activities." Facts on File, XXVII (Septembet 14-20, 1967), 397.

Claxk, Kenneth B. "Introduction: The D11 of Powex." In The Negro American, eda. K. B. Clark and Talcott Parsons. Bostont Houghton MLfflin Company, 1966.

"Clay Urges Parley of Negro Leadexs." The New York Times, July 1, 1967, p. 10 . 
Cleghorn, Reese and Pat Watters. "The Irapact of Negro Votes on Southern Politics." 2he seportor, XxxVI (Januaxy 26, 1967), 24-23.

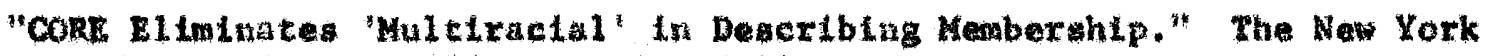
Times, June 6, 1967, pp. 1 and 21 .

Deutsch, Kar1 W. "The National Comuntry: Ito Formation and Relation to the state." In Politice and Geographic Relatloushlps.. ed.W. A. Douglas Jackson, Englewood Cllff, N, J.; Prentice-Hall, Inc., 1964.

"Dr. KIng Says Negro WIII Be Own Man." The Mew York Times, June 19, 1967, 36 .

Dunbar, Ernest. "The Black Revolt HLts the White Campus," Look, XXXI (Ockober 31, 1967), 27-31.

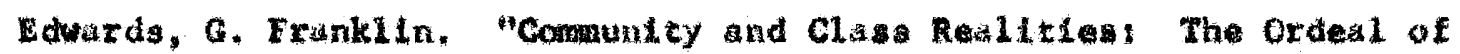
Change." Dued1us, Winter 1965, pp. 1-23.

Fager, Charles E. "Powell and the House: A Black Power Victory?" The Chxiatian Century, Ixxxir (February 8, 1967), 175.

Fanex, James. Fraedom--When? New York1 Randon touse, 1965.

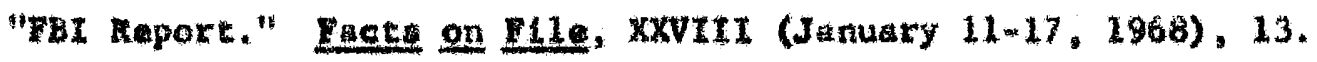

Fihor, Sethard. "Hstay Review-megro Lite atd 3octal Process." Soclal Probleng, XIII (Hinter, 1966), 343-53.

Franklin, Ben A. "SNCC Head Advises "Wegroes in Whaington to Get Cuna." The Naw York Itmes, July 28, 1967, p. 14.

Geschwender, James A. "Foelal Structure and the Negro Revolt An Examinatlon of Sone Hypotheses." Social Zoreeg. XIIII (Decenbar, 1964), 248-255.

"Goals Outlired for coke Meeting." The New Xork Times, June 20, 1967, P. 25.

Gordor, David $M$. "Comenunties of Deapali and the Cfvil Rightg Movenent." The Harvard Raviev, IV (Swmer-7a11, 1966), 49-68.

Grantham, Dewey W., Jr, "The South and the Reconstruction of Amerteun Politico." Journal of American Hiatory, LIII (September, 1966), $227-246$

Haggatrow, Warten C. "The Power of the Poor" In Poverty in America, ad. Louid Aerwan and othara, Am Arbor: The vnlverafty of MLchigar Presa, 1965.

Handin, Oscar and Maxy. The Demblong of Ltborty. Cabridge, Mass. The Belknap Preas of Hervard Vniverstey Presa, 1961. 
Haxtingeon, Mchael. "Introduetion," in Poverty in Amerlea, ed, Loul A. Ferman and others. Ann Arbor: The Univeruley of Michigan Press, 1965.

Mernton, Calvi C. Sex and Racion In Amerlea, Gardan Clty, New York: Doubleday \& Co... Inc., 1905 . - White Raper for White Americans. Garden Chty, Wew Xorik: Doubleday 60 ., Inc. 1966.

Hixson, WLLLiam B. "The Negro Revolution and the Intellectuals." The Amerlcen Scholax, XXX1XI (Autum, 1964), 581-593.

Isaca, Harold $\mathrm{R}$. The Wow World of Herro Amarleang. New York: The John Day Company, 1964.

Jackman, Womman and Jack Dodson, "Wegro Youth and Direct Action," Phylon, XXVIII (Spring, 1967), 5-15.

Johnmon, Thowas. "Negroes Didrupt Newark Farley," The New York Thes, July 23, 1967, p. 18.

- "Boycott of Sports By Negroes Acked." The New York Itoes, July 24, 1967, p. 1 .

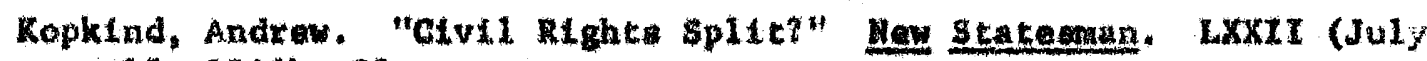
$13,1966), 73$.

- "March Against Black Fear." Lew Scategnan, LXxII (July 1, $1966), 4-5$

Ladd, Everett Carl1, Jx. Megro Polltical Leadership in the South. Thtca, Now York: Cornall University Press, 1956.

Lincoln, C. Erte. "Color and Group Identity in the U. S." Degdlue, Spring 1967, pp. 527-541.

Lomax, Lout. E. The Legro Bevole. Hew Yorkt Harpor Row, 1952.

Lubell, Samul. White and Black. New York: Harper Row, 1964.

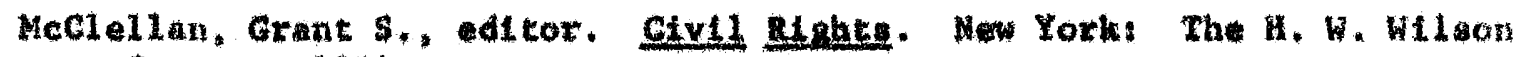
Company, 1964 .

Moynthan, Dantel Patrlok. "Erployment, Incone, and the Ordenl of the Nagro Farily." Baedlus, Fall 1965, pp. 745-770.

"Nashvi11, Riot." Factg on Flle, XXVII (April 27-Hay 3, 1967), 141.

Orwn, Anthony M. "A Reapprafsel of the Bocial and Folitieal Parcicipation of Negroer." Amerloan Journal of Soclology, LxxII (July, 1966), $32 \sim 46$. 
Pettlgrew, Thomas F. A Proftle of the Negro Amerlean. Princeton, N. J.I D. Van Nostrand Company, Ine., 1964.

Piven, Frances Fox and Richard A. Oloward. "What Chance for Black Power?" The New Repub11e. CuvIIT (March 30, 1968), 19-23.

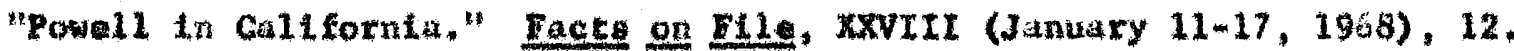

Proctor, Bamuel D. The Young Herto In Amerlca 1960-1920. New Xork: Assoclation Presa, 1956 .

Rainwater, hee, "Crucible of tdentlty: The Negro Lower Clas Family" Dagdiug, Wincer 1966, pp, 172-217.

Revort of the National Advlaory Comigalon on Clvil pleorders. New York: Bantam Books, Ine, 1968 .

"Racisa in Reverse." Eeonomiat, COXX (July 16, 1966), 261.

Robarts, Gene. "The Race Story: Two Negro Leadera," The New York Ilmes, Apri1 16, 1967, Sac. IV, p. 3.

Rogow, Arnold A, and Harold D. Lasewell. Powex, Corruptlon, and Reetitude. Bnglenood Cliffs, N. J.: Prentice Hall, Tne., 1963.

"Shaden of Black Power." Econonisk, Coxk (September 3, 1966), 909-910.

Simpsor, Victor L. White Viglantes, Negro Miltants, Escalate Arms Bace la Growing Unzant in New Jersey." The Oregontan, March 17, $1968, p .21$.

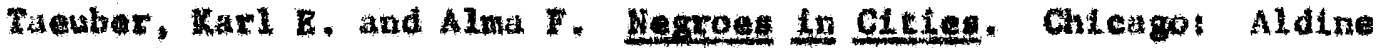
Publinting Company, 1963.

"The Many Meanings of Black Power." The New Xork Tlmes, July 23, 1967, Sea. IV, p. 1 .

The Nenroes in the United States Their Eeonomie and Soclal situation. Depart ent of Labor, Bulletin No. 1511. Wahington; Goverrment Printing offlee, 1966.

"Thivking B1ack." Neweveak, LXx (Novuber 20, 1967), 37-41.

Waste, Frank R. "The Amerlean Dilema: An Eaplrieal Test." American Soctologlast Revieu, XXX (Auguat, 1965), 527-538.

"What Must Be Done." Nevgueds, LxK (Novwber 20, 1967), 33-37.

Wheeler, John H. "CIVI1 Right Groups--Their Irapact Upon the War on Poverty." Lav and Contenporary Problems, XXXI (Winter, 1966), $152-158$ 
"Whiteh Way for the Negro?" Newoweek, LXIX (May 15, 1967), 27-34.

Zeigler, Hamon. Interest Groups Ln Anerican Society. Englewood Cliffs, N. J.: Prentice-Hall, Ine. 1964 .

ZInn, Howard. The Naw Abolltionlsts, Boston: Bacon Press, 1964. 